\title{
Climate of the Last Glacial Maximum: sensitivity studies and model-data comparison with the LOVECLIM coupled model
}

\author{
D. M. Roche ${ }^{1}$, T. M. Dokken ${ }^{2}$, H. Goosse ${ }^{3}$, H. Renssen ${ }^{1}$, and S. L. Weber ${ }^{4}$ \\ ${ }^{1}$ Department of Palaeoclimatology and Geomorphology, Faculty of Earth and Life Sciences, Vrije Universiteit Amsterdam, \\ De Boelelaan 1085, 1081 HV Amsterdam, The Netherlands \\ ${ }^{2}$ Bjerknes Center for Climate Research, Allegaten 55, 5007 Bergen, Norway \\ ${ }^{3}$ Institut d'Astronomie et de Géophysique G. Lemaître. 2, Chemin du Cyclotron, 1348 Louvain-la-Neuve, Belgium \\ ${ }^{4}$ Royal Netherlands Meteorological Institute (KNMI), P.O. Box 201, 3730 AE De Bilt, The Netherlands
}

Received: 9 October 2006 - Published in Clim. Past Discuss.: 8 November 2006

Revised: 21 February 2007 - Accepted: 3 May 2007 - Published: 15 May 2007

\begin{abstract}
The Last Glacial Maximum climate is one of the classical benchmarks used both to test the ability of coupled models to simulate climates different from that of the present-day and to better understand the possible range of mechanisms that could be involved in future climate change. It also bears the advantage of being one of the most well documented periods with respect to palaeoclimatic records, allowing a thorough data-model comparison. We present here an ensemble of Last Glacial Maximum climate simulations obtained with the Earth System model LOVECLIM, including coupled dynamic atmosphere, ocean and vegetation components. The climate obtained using standard parameter values is then compared to available proxy data for the surface ocean, vegetation, oceanic circulation and atmospheric conditions. Interestingly, the oceanic circulation obtained resembles that of the present-day, but with increased overturning rates. As this result is in contradiction with the current palaeoceanographic view, we ran a range of sensitivity experiments to explore the response of the model and the possibilities for other oceanic circulation states. After a critical review of our LGM state with respect to available proxy data, we conclude that the oceanic circulation obtained is not inconsistent with ocean circulation proxy data, although the water characteristics (temperature, salinity) are not in full agreement with water mass proxy data. The consistency of the simulated state is further reinforced by the fact that the mean surface climate obtained is shown to be generally in agreement with the most recent reconstructions of vegetation and sea surface temperatures, even at regional scales.
\end{abstract}

Correspondence to: D. M. Roche

(didier.roche@falw.vu.nl)

\section{Introduction}

For climate modellers, the Last Glacial Maximum (LGM) is a standard period to evaluate their model's capability to simulate a climate that is drastically different from that of the present-day. These evaluations have been supported by several projects aimed at the reconstruction of the LGM surface conditions based on proxy data, like CLIMAP (CLIMAP, 1981), GLAMAP2000 (Sarnthein et al., 2003) and MARGO (Kucera et al., 2005a), providing strong constraints on what the climate looked like at that period of time. At the same time, efforts have been undertaken to improve intercomparisons of the different models under glacial boundary conditions such as the pioneering work of the Palaeoclimate Modeling Intercomparison Project (PMIP). In its first phase PMIP applied Atmospheric General Circulation models (Joussaume and Taylor, 2000), followed by Coupled Atmospheric-Ocean models in its second phase (PMIP2) (see also website http://pmip2.lsce.ipsl.fr Crucifix et al., 2005; Braconnot et al., 2007). Comparisons between PMIP models were also conducted to evaluate the results against surface data of the LGM (Kageyama et al., 2001, 2006). Those comparisons have shown that the inclusion of more components in the climate system have resulted in better agreement with the data (Kageyama et al., 2006). At the same time, some work on data assimilation of MARGO data in a simplified coupled model (Paul and Schäfer-Neth, 2005) has proven the significance of the mean surface climate in determining the consistency of the simulated climate with respect to data.

However, there is still strong disagreement between models with respect to one of the major components of the climate system: the oceanic thermohaline circulation (THC). In the few LGM experiments conducted with coupled Atmosphere-Ocean models (Kitoh et al., 2001; Hewitt et al., 2003; Shin et al., 2003; Kim, 2004) the strength of the

Published by Copernicus GmbH on behalf of the European Geosciences Union. 
thermohaline circulation and the relative importance of the different water masses differs considerably. Mechanisms underlying the simulated THC response were found to differ widely in an inter-comparison study of PMIP coupled model simulations (Weber et al., 2007). The current palaeoceanographic interpretation of data is a weaker overturning, with a shallower North Atlantic water mass and a denser and more predominant Antarctic water mass. However, some uncertainties remain on the precise relationships between the water masses.

In this study, we present an extensive comparison between our simulated LGM climate and available data to evaluate the agreement between the two. We consider both the surface climate and the deep ocean circulation. We have also performed a suite of sensitivity experiments to study the response of the glacial ocean circulation to different model parameters. The aim is to assess how different setups may yield different types of global meridional circulation.

A precise definition of the LGM is required. Although it originally refers to the maximum of globally averaged continental ice that occurred during the last glacial period, it is usually difficult to derive that period from a given data archive. Thus, the period taken depends on the archive (Sarnthein et al., 2003, for example). In this paper, we will further refer to the LGM as the period around 21 thousand years before present (kyrs B.P.), coherent with the commonly used time period in previous climate simulations and being also the centre of the period used in most recent reconstructions (Kucera et al., 2005a).

\section{The LOVECLIM model and the LGM}

\subsection{Model description}

In this study we use the three-dimensional Earth System model LOVECLIM. LOVECLIM is an acronym made from the names of the five different models that have been coupled to build the Earth system model: LOch-Vecode-EcbiltCLio-agIsm Model (LOVECLIM, Driesschaert, 2005). Here only the atmosphere-ocean-vegetation part is used (ECBiltCLIO-VECODE). Actually, in the configuration chosen here, the model gives exactly the same results as ECBiltCLIO-VECODE version 3, used for instance by Goosse et al. (2005) and Renssen et al. (2005) to study the climate of the past millennium and of the Holocene respectively (but is substantially different from the one used by Timmermann and Goosse, 2004). Nevertheless, many technical changes have been included in the code recently, in particular in order to allow for the coupling with ice sheet and carbon cycle models. As a consequence, for simplicity, users and developers have decided jointly that the new name LOVECLIM should now be used for the model, even if some components are not activated (see http://www.astr.ucl.ac.be/index.php?page= LOVECLIM@SumLove).
The atmospheric model is a global quasi-geostrophic, spectral model at T21 horizontal resolution, with additional parameterisations for the diabatic heating due to radiative fluxes, the release of latent heat, and the exchange of sensible heat with the surface (Opsteegh et al., 1998). The ocean part is a three dimensional, free surface, general circulation model coupled to a thermodynamical and dynamical sea-ice model (Goosse and Fichefet, 1999). The vegetation part is the VECODE dynamical terrestrial vegetation model (Brovkin et al., 1997) which computes plant fractions for trees and herbaceous (plus desert) from several atmospheric variables in each land grid-cell. To easily compare the output of VECODE with available vegetation reconstructions for the LGM, we developed a module to assign biomes from the Plan Functional Types (PFTs) computed by the vegetation model (see Sect. 2.3).

As such, the Earth system model used here is able to simulate the climate with some details while still being computationally efficient, and therefore allows for multi-millenial simulations. This ability is used extensively here, in order to test the model with respect to the different parameter values in the range of possibilities, in particular with respect to the oceanic circulation.

This coupled model was validated for the pre-industrial climate (Driesschaert, 2005), a state used here as starting point for our simulations. It will be hereafter referred to as LH_CTRL (Late Holocene, used as Control).

\subsection{LGM boundary conditions}

To simulate the Last Glacial Maximum (LGM) climate, we use the following boundary conditions according to the PMIP2 protocol. Atmospheric greenhouse gas concentrations are modified in agreement with ice-core measurements (Fluckiger et al., 1999; Dällenbach et al., 2000; Monnin et al., 2001), implying lowered levels of $\mathrm{CO}_{2}, \mathrm{CH}_{4}$ and $\mathrm{NO}_{2}$ (with values of $185 \mathrm{ppm}, 350 \mathrm{ppb}$ and $200 \mathrm{ppb}$, respectively). Orbital parameters correspond to $21 \mathrm{kyr} \mathrm{BP}$ (Berger and Loutre, 1992). Ice-sheet topography changes are taken from Peltier (2004) and the surface albedo is set accordingly. The landsea mask and the oceanic bathymetry are modified to account for the lowering of sealevel by $120 \mathrm{~m}$ relative to present (Lambeck and Chappell, 2001). Some variations exist among the PMIP simulations in the handling of changes in the river basins (Weber et al., 2007), i.e. changes in river routing due to the presence of ice-sheets. This mainly concerns the Northern Hemisphere. In the present LGM simulation we included changes in the output of water from the Laurentide ice-sheet in North America and from the Fennoscandian icesheet in Eurasia. We also include changes in river runoff from Antarctica (i.e. calving) which is displaced towards the equator, to account for the likely location of melting of icebergs in this colder climate, as is shown by iceberg models (J. Jongma, personal communication). 
Table 1. Constraints used to compute the biome distribution from the PFTs simulated by the VECODE vegetation model. $\mathrm{T}_{c}$ is the coldest month temperature, $\mathrm{T}_{w}$ the warmest month temperature, $\mathrm{GDD}_{5}$ and $\mathrm{GDD}_{0}$ are the standard 0 and 5 degrees Growing Degree-Days (see for example Prentice et al., 1992). " $\mathrm{T}_{c}$ min" means a constraint on the minimum allowed for coldest month temperature, " $\mathrm{T}_{c}$ max" means a constraint on the maximum allowed for the coldest month temperature.

\begin{tabular}{|c|c|c|c|c|c|}
\hline & $\mathrm{T}_{c} \min$ & $\mathrm{T}_{c} \max$ & $\mathrm{GDD}_{5} \min$ & $\mathrm{GDD}_{0}$ & $\mathrm{~T}_{w} \min$ \\
\hline \multicolumn{6}{|l|}{ Trees } \\
\hline Tropical broadleaf forest & $15.5^{\circ} \mathrm{C}$ & & & & \\
\hline Warm mixed forest & $5^{\circ} \mathrm{C}$ & $15.5^{\circ} \mathrm{C}$ & & & \\
\hline Temperate broadleaf forest & $-2^{\circ} \mathrm{C}$ & $5^{\circ} \mathrm{C}$ & & & \\
\hline Cool mixed forest & $-2^{\circ} \mathrm{C}$ & $5^{\circ} \mathrm{C}$ & & & \\
\hline Cool conifer forest & $-15^{\circ} \mathrm{C}\left(-19^{\circ} \mathrm{C}\right)$ & $-2^{\circ} \mathrm{C}$ & 1200 & & \\
\hline \multicolumn{6}{|l|}{ Boreal forest } \\
\hline \multicolumn{6}{|l|}{ Herbaceous } \\
\hline Tropical savanna & $17^{\circ} \mathrm{C}$ & & & & \multirow{5}{*}{$22^{\circ} \mathrm{C}$} \\
\hline Warm grass & & & & & \\
\hline Cool grass & & & 500 & & \\
\hline Tundra & & & & & \\
\hline Semi-desert (cold or warm) & & $22^{\circ} \mathrm{C}$ if hot & & $>100$ if cold & \\
\hline \multicolumn{6}{|l|}{ Desert } \\
\hline Polar desert & & & & $<100$ & \\
\hline Hot desert - steppe & $>22^{\circ} \mathrm{C}$ & & & & \\
\hline
\end{tabular}

In addition to the PMIP boundary conditions, we took the dust forcing due to the ice-age atmospheric dust loading (Claquin et al., 2003) into account in the incoming solar radiation at the top of the atmosphere. Also, the lower glacial $\mathrm{CO}_{2}$ levels are taken into account in the vegetation part (Harrison and Prentice, 2003) of the LOVECLIM model. We then applied these forcings to the model's equilibrium LH_CTRL state and integrated it until a new equilibrium was reached, after about 5000 years of integration.

\subsection{Biome estimations from VECODE}

To better compare the results of VECODE (Brovkin et al., 1997) with proxy data, we have developed a module to compute biomes, using both VECODE and ECBilt output. This module is based on the approach of Prentice et al. (1992), with some simplifications. We here considered only the 12 biomes thought to be the most appropriate with respect to the level of the complexity of the VECODE vegetation model and the resolution of the ECBilt atmospheric model. In particular, VECODE only computes two main Plant Functional Types (PFTs): herbaceous and trees. The "tree" PFT is split in terms of needleleaved and broadleaved trees. It also computes a desert fraction. The sum of the three fractions (trees, herbaceous and desert) equals one. In cells with a prescribed ice-sheet, we assign all PFTs' fractions to zero and the desert fraction to 1 . The environmental limits used to convert the PFT distribution computed by VECODE are given in Table 1. For each cell, we first compute the dominating PFT in the cell and then apply the environmental constraints in order to assign a biome. In contrast with Prentice et al. (1992), we did not retain any biomes based on the dominance of shrubs as they are not a PFT in VECODE.

Additionally, we have added a tree growing limitation with respect to $\mathrm{CO}_{2}$ in order to take into account the effect of higher herbaceous competitiveness under lowered atmospheric $\mathrm{CO}_{2}$ conditions (Harrison and Prentice, 2003), as has been the case during the LGM.

\section{Overview of the simulated LGM climate}

\subsection{Surface Air Temperature (SAT) changes}

The simulated LGM climate we obtain presents a reduction of $-4.4^{\circ} \mathrm{C}$ in global mean surface temperature. This result compares well with the PMIP2 models' mean changes of $-4.45^{\circ} \mathrm{C}$ (Kageyama et al., 2006, for 6 models) in air temperature. Figure 1 presents the change in global surface temperature between LGM and LH_CTRL, together with the changes in seasonal amplitude simulated under LGM conditions with respect to LH_CTRL. 

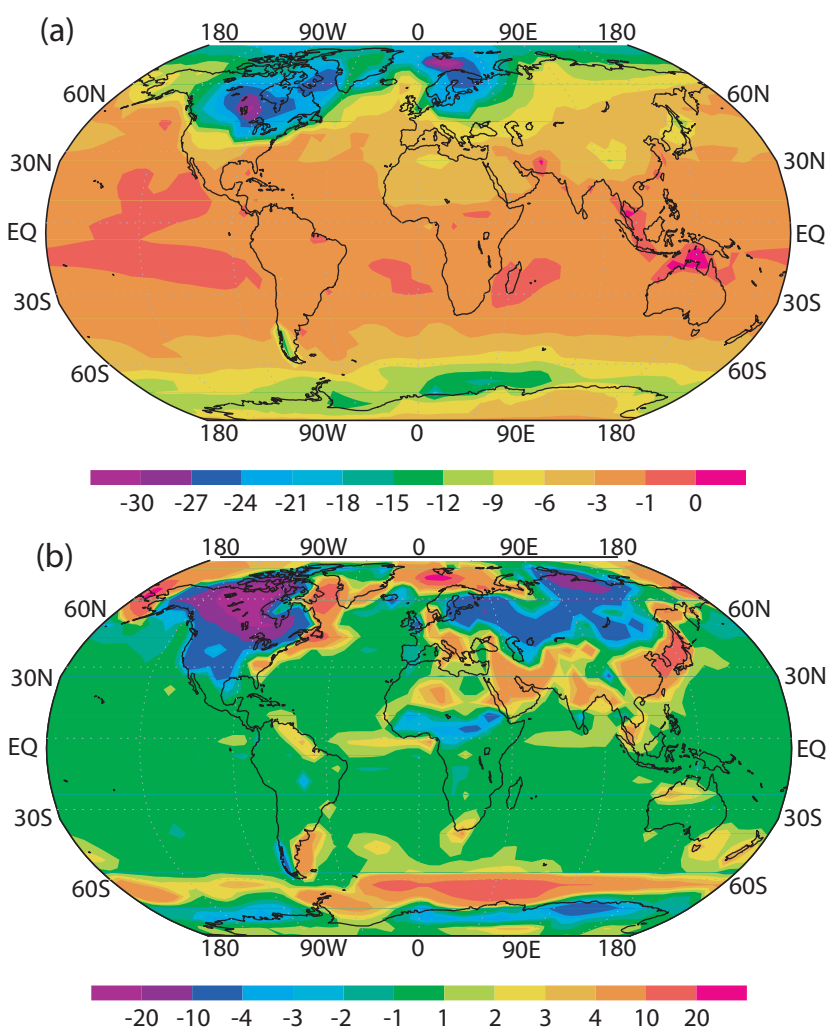

Fig. 1. Changes in simulated SAT at the LGM with respect to the LH_CTRL (in ${ }^{\circ} \mathrm{C}$ ). Panel (a) shows the annual SAT anomaly (LGMLH_CTRL) over the globe. Panel (b) show the anomaly (LGMLH_CTRL) in seasonal range, defined as being the warmest month minus the coldest month surface air temperature for each of the two climates. All panels show averages over the last 200 years of the simulations.

Changes in SAT (Fig. 1a) show much colder temperatures on the prescribed permanent ice-sheet (up to $-30^{\circ} \mathrm{C}$ in the centre of Laurentide and Fennoscandian ice-sheets, and up to $-6^{\circ} \mathrm{C}$ at the border) due to the changes of altitude and albedo. Differences of -6 to $-15^{\circ} \mathrm{C}$ are simulated over the additional sea-ice covered regions as a response to seasonal or perennial isolation from the atmosphere and albedo effect. Nearby land points also exhibit comparable changes due to the albedo effect of increased snow cover. A cooling of 1 to $2^{\circ} \mathrm{C}$ is simulated in most of the tropical and equatorial regions with the exception of no changes over the north of Australia (Sea of Arafora).

We define the seasonal range as being the warmestcoldest month anomaly in surface air temperature. LGM to LH_CTRL differences in seasonal range are shown in Fig. 1 b. The seasonal range at the LGM is increased globally by $9.7^{\circ} \mathrm{C}$ with respect to the LH_CTRL simulation. This number however hides large regional differences. We can distinguish three different zones. a) LGM ice-sheet regions like North America and Scandinavia where the seasonal range is much less than in the LH_CTRL simulation $\left(-4\right.$ to $\left.-20^{\circ} \mathrm{C}\right)$. This is due to the fact that these regions have a high seasonal range in the present-day, but the seasonal differences are dampened by the all-year cold climate of the LGM, due to the presence of the ice-sheets (this also holds for the Patagonian ice-cap). This is also true for nearby regions like Siberia, where the seasonal range is reduced due to longer snow cover and cooler summers. b) Regions where there are already ice-sheets in the present-day (Greenland, Antarctica) and over oceans between $40^{\circ} \mathrm{N}$ and $40^{\circ} \mathrm{S}$. These regions undergo small SAT seasonality changes with respect to the LH_CTRL ( -1 to $\left.1^{\circ} \mathrm{C}\right)$, as they are much unchanged by the LGM climate (mainly cooled down by a few degrees). c) Continental regions in general (and extended deserts in particular) and oceans near ice-sheets and regions with extended sea-ice cover which have a much higher seasonality in the LGM than in the present-day. All these regions are much colder at the LGM during winter time (extension of sea-ice enhanced the effect, neighboring ice-sheet implying snow cover, colder inland and bright desert regions - all an albedo effect, mainly).

\subsection{Changes in the hydrological cycle}

In the global mean, there is a decrease of the total amount of precipitation by $13 \mathrm{~mm} \mathrm{yr}^{-1}$, consistent with a decrease in the evaporation due to the global cooling (see Fig. 2a). Some regions undergo a drastic reduction in the rate of annual mean precipitation, such as the southern border of the Sahara, the middle- and far- East, some parts of central Asia (in particular the Tibetan Plateau) and central Greenland - a feature consistent with snow accumulation data (Cuffey and Clow, 1997; Alley, 2000) - and Western Canada. There is also some consequent diminution of precipitation in southern Europe - consistent with both other model results and proxy data (Tarasov et al., 1999; Peyron et al., 2005; Jost et al., 2005) -, some parts of Siberia, Svalbard, Japan and southern America (Argentina and southern Chile). The decrease of precipitation observed in South America is consistent with the fact that this region was a source of dust in the LGM (Grousset et al., 1992; Basile et al., 1997).

As can be inferred from Fig. 2b, the changes in precipitation occurring in the Northern Hemisphere are mainly due to the displacement of the winds tracks, as a consequence of the presence of ice-sheets. Interestingly, the simulated changes show a maximum increase of precipitation over the southern border of the Laurentide ice-sheet (a feature also reported by Kageyama and Valdes, 2000, and Vettoretti et al., 2000) and on the western flank of the Fennoscandian icesheet. The increase in precipitation over these areas is crucial for maintaining ice-sheets at the LGM, both for the southern part of the Laurentide ice-sheets, which presents a lobe advance in this region (Peltier, 2004), and for the Fennoscandian ice-sheet. It is an important pre-requisite to be able to simulate the advance and volume of the last glacial 
ice-sheets, especially the Fennoscandian one (Forsström and Greve, 2004; Charbit et al., 2006).

The changes in the precipitation pattern in the LGM therefore seem to be quite comparable with other LGM studies (Vettoretti et al., 2000) as well as favourable to maintain the extensive (prescribed here) ice-sheet of the LGM period.

\subsection{Changes in simulated vegetation cover}

Globally the simulated changes in vegetation cover are responses to the cooler and dryer conditions which prevail in the simulated LGM climate described here. For the three Plant Functional Types (PFTs) simulated, VECODE simulates the following evolutions in the LGM with respect to LH_CTRL (not shown).

The desert fraction is expanded in central Asia, the Sahara and southeast America, reflecting the drier conditions prevailing there. Some polar desert appears in northeastern Siberia (which denotes extreme cold and dry conditions, compatible with the absence of an ice-sheet in this area during the LGM, see Svendsen et al., 2004).

Tree fractions are reduced overall, as low as zero in certain regions. For example, the cooling of the climate and the lowering of the atmospheric $\mathrm{CO}_{2}$ level causes disappearance of the LH_CTRL forests of central Russia and Siberia in favour of herbaceous areas. The model furthermore simulates the shrinking of the tropical broadleaf forests (Amazonia and tropical Africa) in response to drier conditions (see Fig. 2a). In the case of northern America, we can make a direct comparison between simulated PFTs and proxy-based reconstructions for the tree cover in the LGM (Williams, 2002). VECODE correctly simulates a mixture of needleleaved and broadleaved trees on the east coast of America, with a high tree cover until the southern boundary of the Laurentide ice-sheet. The central part of the United States is correctly covered predominantly by grass with few trees (0-15\%). However, our simulation shows dense tree cover in the western United States for the LGM, a feature which is not seen in proxy data (Williams, 2002). This feature is also present in the LH_CTRL simulation which shows a too large tree cover in this region for the Late Holocene. This is due to the too humid state simulated in this area for both climates.

Grass fractions are increased in regions where the tree area shrinks, and in particular in central Asia, southern Europe, western Africa and eastern Brazil.

All these changes are broadly consistent with the changes found in pollen distributions for the LGM (Prentice et al., 2000 , for example). However, as it is common to describe the reconstructions of vegetation in terms of biomes, we considered it useful to develop an approach that computes biomes from the available PFTs distribution and climatic variables in a simple manner (as presented in Sect. 2.3). The results obtained in this development are described in Sect. 4.1, and enable a detailed data-model comparison for our simulated LGM climate.
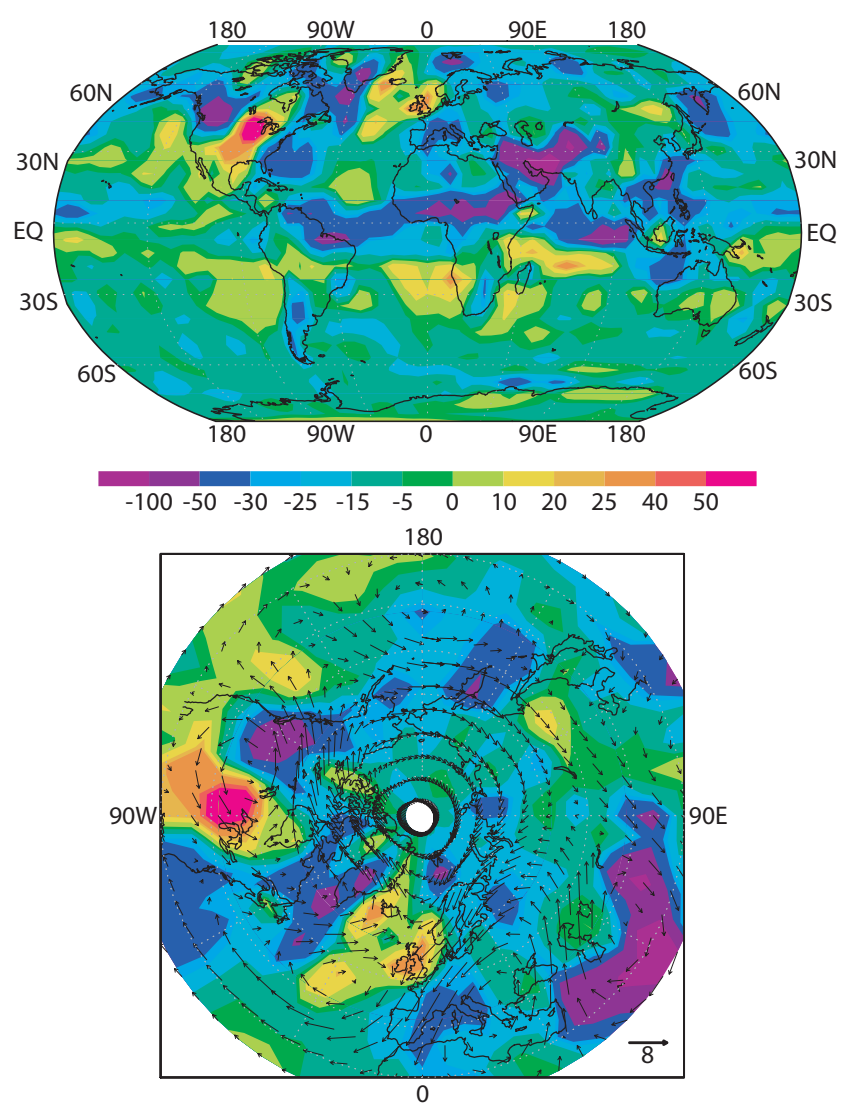

Fig. 2. Changes in simulated precipitation at the LGM with respect to the LH_CTRL (in $\mathrm{mm} \mathrm{yr}^{-1}$ ). Panel (a) shows the precipitation anomaly (LGM-LH) over the globe. Panel (b) shows the precipitation anomaly (LGM-LH) for the Northern Hemisphere, with LGM to LH_CTRL changes in the wind field (at $850 \mathrm{hPa}$ ) superimposed as vectors. All panels show averages over the 200 last years of the simulations.

\subsection{Changes in the deep ocean circulation}

The location of deep water formation in the Northern Hemisphere is shifted from the Labrador and Nordic seas for LH_CTRL to the south of Iceland and Greenland in our LGM simulation, with some convection remaining in the Nordic seas (Fig. 3c). These changes are accompanied by a reduction of the maximum depth of direct ventilation by about $600 \mathrm{~m}$. The maximum convection depth is still reached in the Nordic seas $(1800 \mathrm{~m})$, marginally deeper than south of Iceland $(1400 \mathrm{~m})$. However, the convection site south of Iceland is more permanent, whereas the activity of the Nordic Seas site depends on the year considered.

In the Southern Hemisphere there are few changes in the depth reached by convection, but an important shift in the location of deep water production is noted (Fig. 3d). Whereas in LH_CTRL sinking waters are formed partly along the coast of Antarctica (plus the Weddell and Ross seas) and partly further away from the continent, this latter source 

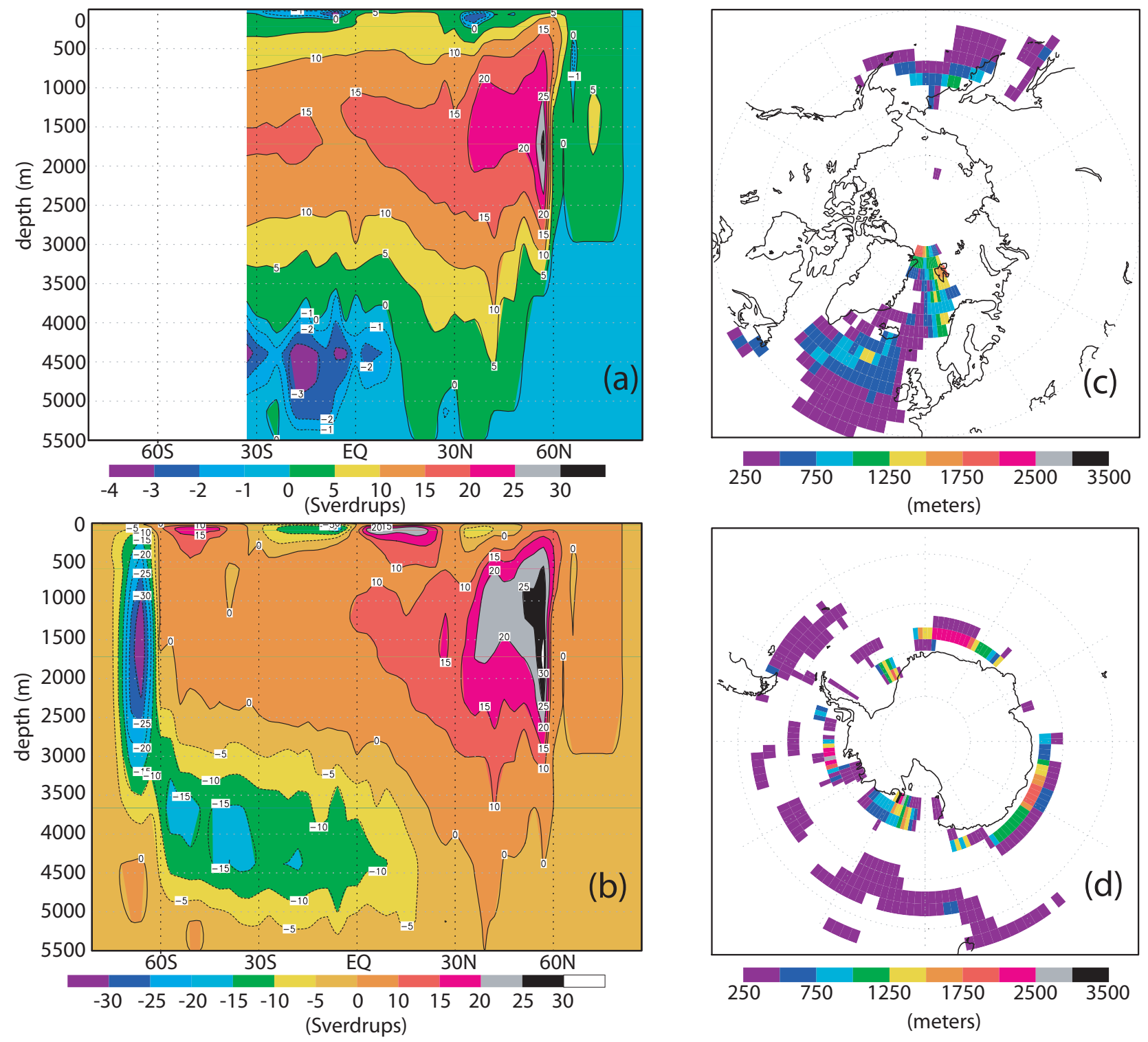

Fig. 3. LGM Meridional overturning streamfunction for the Atlantic (panel a) and the world (panel b) oceans. Contours are in Sverdrup, positive (respectively negative) values denote clockwise (resp. counterclockwise) flow. LGM maximum convective depth around Antarctica (panel d) and in the north Atlantic and Nordic Seas (panel c); depth is labeled in metres. Panels (a) and (b) show averages over the 200 last years of the simulation, panels (c) and (d) maximum over the same time interval. We show the maximum convective depth, thought to be more indicative of the real depth attained by the deep water masses.

disappears in the LGM simulation and the former is reinforced. There is open ocean convection along the coast of Antarctica in all sectors of the Southern Ocean, the strongest and deepest being in the Atlantic sector. As a result of this shift in the location of convection, there is a strong enhancement of AABW production that is doubled in the LGM simulation with respect to LH_CTRL. This evolution is related to a decrease of sea-ice production on the continental shelf in the LGM compared to LH_CTRL, the large sea-ice extent obtained promoting sea-ice formation further away from the continent.
The total rate of North Atlantic Deep Water (NADW) formation is stronger in the LGM simulation than in LH_CTRL. The associated meridional overturning streamfunction is shown in Fig. 3 (see Appendix A for LH_CTRL results). The simulated oceanic water export at $20^{\circ} \mathrm{S}$ is about $16.4 \mathrm{~Sv}$ with respect to a $13.8 \mathrm{~Sv}$ LH_CTRL value (enhanced by $2.6 \mathrm{~Sv}$ ), as is shown in Fig. 3a. The input of AABW in the Atlantic at $20^{\circ} \mathrm{S}$ is $2.6 \mathrm{~Sv}$ in the LGM compared to $7 \mathrm{~Sv}$ in LH_CTRL, thus experiencing a decrease of $4.4 \mathrm{~Sv}$. This is in contradiction with the prevailing view of the LGM Atlantic ocean circulation, which is believed to be less active, shallower, 

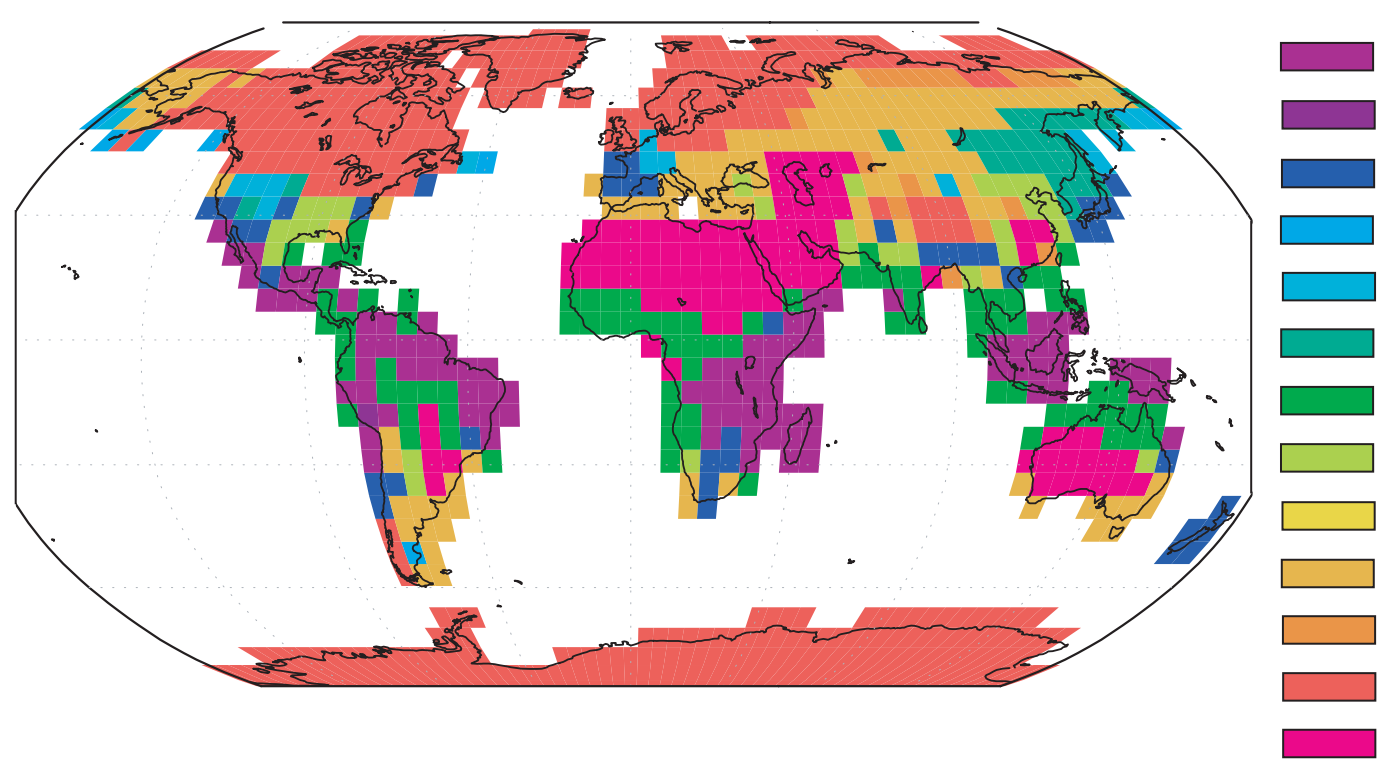

Tropical forest

Warm mixed forest

Temperate broadleaf

forest

Cool mixed forest

Cool conifer forest

Boreal forest

Tropical savanna

Warm grass

Cool grass

Tundra

Semi-desert

(cold/warm)

Polar desert

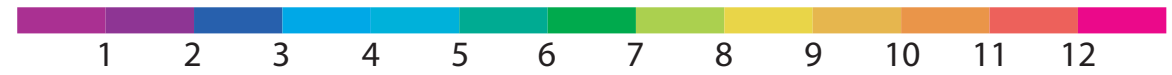

Hot desert - Steppe

Fig. 4. Estimated biomes in the LGM simulation. See Sect. 2.3 for the method of estimation.

and with an increased AABW import in the Atlantic basin (Ganopolski et al., 1998; Rahmstorf, 2002; Shin et al., 2003). There is however no agreement on the strength of the glacial thermohaline circulation in coupled model simulations of the LGM (Hewitt et al., 2003; Mix, 2003; Shin et al., 2003; Timmermann and Goosse, 2004; Kim, 2004), some obtaining stronger overturning and some weaker. In fact, a recent comparison of the LGM ocean circulations in different PMIP simulations (Weber et al., 2007) showed that half of the models produce an increase in overturning rate under glacial boundary conditions. In particular there is much debate on the relative strength of the Glacial Antarctic Bottom Water (GAABW) and Glacial North Atlantic Deep/Intermediate Water (GNADW/GNAIW) in the LGM (Paul and SchäferNeth, 2003). The relative proportion of these water masses is being controlled by the relative density of the two; to obtain a stronger inflow of deep Antarctic water, this water mass should be much denser than that of the deep north Atlantic. In our simulation, the GNADW is slightly denser on average than the GAABW, which then prevents considerable AABW presence in the Atlantic basin. There are however some multi-centennial variations in the deep convection, with periods of reduced GNADW formation in the GIN seas, enabling the entrance of more GAABW - more than a doubling during one to two hundred years. The simulated ocean state is thus variable, so that the average state may not be the most appropriate view of it (Hewitt et al., 2006). In Sect. 4.5 we will critically discuss the state obtained here with respect to available data.

\section{Model-data comparison}

\subsection{Simulated vegetation}

In this sub-section, we discuss the simulated vegetation in our LGM climate in terms of biomes with respect to available reconstructions (see Table 1 for the bioclimatic ranges used in classification). Hereafter, we discuss each main regions separately; the biomes discussed are presented in Fig. 4.

1. Siberia. In the model, we simulate the disappearance of much of the present-day boreal forest type which is replaced by a mixture of tundra and cool grass types. The non-glaciated area of the northwestern Alaska and Beringian regions are defined as the tundra biome type. These results are more or less in line with available proxy data, in particular with the Bigelow et al. (2003) compilation which depicts different types of tundra over Bering, a small part of northwestern Canada and northern Siberia, except for two sites in Siberia with Temperate Grassland biome (Bigelow et al., 2003; Kaplan et al., 2003) which replaces the Siberian cool-mixed/boreal forests existing in the present-day.

2. We simulate in southwestern Europe a mixture of temperate trees and cool grass biome types. This reflects the too warm/moist conditions prevailing south of the Fennoscandian ice-sheet in our simulation; this feature is not consistent with available data for this region. Cool grass is attributed as the dominant biome in southeast Europe. This second part is much in line with the 
compilation of Ray and Adams (2001) which depicts southern Europe as being dominated by steppe-like conditions with some trees in the more moist areas, and also with the compilation of Prentice et al. (2000).

3. In northern Africa, there is a general drying, promoting the southward extension of the desert regions $-\mathrm{Sa}$ hara type - by 5 to (locally) $11^{\circ}$, at the expense of the tropical Savanna simulated in the LH_CTRL simulation. This result is fairly consistent with the southward extension of the Sahara desert boundary by $5^{\circ}$ of latitude, as depicted by Prentice et al. (2000) and Ray and Adams (2001).

4. The regions of tropical forest in central Africa, although already too small in extension in the LH_CTRL simulations, are nevertheless smaller in the LGM simulation, with the disappearance of this particular biome along the Atlantic seaboard. Conversely, the tropical forest cover, too extensive already at present-day on the Indian side, is preserved in our LGM simulation. The shrinking - without disappearance - of the tropical forest areas in central-west Africa is in line with current reconstructions (Dupont et al., 2000; Ray and Adams, 2001; Leal, 2004), although our simulation of extensive tropical forests on the Indian ocean side is unrealistic. This discrepancy between data and model is also found in South America, and is due to an incorrect representation of the zones of high precipitation in the ECBilt model, promoted on the eastern side of the continents instead of more central regions.

5. Central Asia is a place of great expansion of desert and semi-desert biomes in our LGM simulation with respect to the LH_CTRL, with, in particular, the appearance of a great desert in central China, surrounded by a cool grass biome replacing most of the simulated LH_CTRL warm grass/cool forest. Some regions of tundra and cold semidesert slightly expand around the Tibetan plateau. Not many changes are seen in the tropical belt (India, southeast Asia and Indonesia) with respect to the LH_CTRL simulation, albeit from slight drying conditions inland in southeast Asia. Japan sees the replacement of a mixture of warm/temperate forest in the LH_CTRL simulation with a complete cover of temperate forest in our simulated LGM. All these features are broadly consistent with the current compilations. Some discrepancies are however notable; in general the model simulates a too wide extension of forests in northeast China and southeast Asia, whereas pollen estimations yield more steppish conditions in those areas. Ray and Adams (2001) mention the expansion of deserts in central Asia and the shrinking of tree cover in China. The LGM vegetation of Japan is seen as a mixture of cool mixed forest to temperate forest in data (Prentice et al., 2000), not inconsistent with our simulated dominance of temperate forest, although the data suggests colder conditions in the northern part.

6. As already discussed, south of the Laurentide icesheet we simulate the cover of tree and grass relatively well according to proxy data available for these PFTs (Williams, 2002). In terms of inferred biomes, central U.S.A. is covered by the "warm grass" biome in our simulation, whereas reconstructions point to "tundra" (Prentice et al., 2000) or "temperate grassland" (Ray and Adams, 2001). The absence of trees in our result is thus consistent with these reconstructions. On the eastern Atlantic coast we simulate a bioclimatic gradient from "tropical savanna" (in Florida) to "tundra"/"temperate forest" (at the ice-sheet border). In data these regions are depicted as "open conifer woodland" in Florida to "taiga" of "cool mixed forest" in the north (Prentice et al., 2000; Ray and Adams, 2001). Therefore, the model exhibits some exaggeratedly warm conditions in southeastern USA with respect to data, but is not too far off at the ice-sheet border. Towards the Pacific coast, we obtain a mixture of "temperate forest" to "cool conifer forest" with some tundra, compared to "tundra" and "cool conifer" in data (Prentice et al., 2000). This area seems therefore quite consistent with proxy data. Southward we have a fairly extensive cover of "tropical forest" in Central America, outlining the too humid conditions we simulate there compared to data (Ray and Adams, 2001).

7. In South America, our estimated biomes show two main patterns: a slight northwards migration of the Amazonian forest by 5 to (locally) $11^{\circ}$ of latitude and a general drying of the Argentinian and Uruguayan regions (semidesert and cool grass biomes). These results for the Amazonian forest are in line with proxy data, although the state of the Amazonian forest at the LGM is still quite controversial (Colinvaux and de Oliveira, 2000; Ray and Adams, 2001; Leal, 2004, for example). The drying of the southeastern part of South America (and especially of the shelves exposed during the LGM) is seen in data, and recorded as dust deposits in the Antarctic ice-cores. We also find some areas of desert and semi-desert in south America (Ray and Adams, 2001).

8. Finally our simulation of vegetation in Australia shows an important increase of the desert and semi-desert biomes in our LGM simulations at the expense of the forest cover (LH_CTRL), which is limited to the coastline. These results are in good agreement with current reconstructions which show extreme desert in the centre of Australia with overall less forest cover (Ray and Adams, 2001; Prentice et al., 2000). In northern Australia, we simulate drier grass-dominated conditions in line with available data. The simulated savanna does not have a significant fraction of trees, therefore 
representing the dry and open conditions prevailing in this area at the LGM.

\subsection{Land temperatures: permafrost in Europe}

A good indicator of the mean cooling of the climate is the limit of the permafrost. In this sub-section, we therefore try to compare the simulated LGM climate with data for the permafrost limits in Europe, following the types and limits of Renssen and Vandenberghe (2003), namely: 1) discontinuous permafrost exits if annual mean temperature is below $-4^{\circ} \mathrm{C}$ and 2) continuous permafrost exists if both mean annual temperature is below $-8^{\circ} \mathrm{C}$ and the coldest month temperature is below $-20^{\circ} \mathrm{C}$.

Figure 5 shows the limits of the continuous and discontinuous permafrost as simulated for the LGM with the limits estimated from proxy data. It is striking that the simulated area of permafrost is much too small with respect to proxy data, with continuous permafrost simulated only for Scandinavia and the Baltic States whereas it should extend up to Belgium, the south of Germany and all off the United Kingdom and Ireland (Renssen and Vandenberghe, 2003). This underestimation indicates that we overestimate temperatures over western Europe, which is related to the anomalously warm conditions over the nearby Atlantic Ocean (see Sect. 4.3). Moreover, we do not simulate continuous permafrost over the British Isles, even if there is a prescribed ice-sheet over their northern reaches. This is probably due, in part, to the resolution of the model: the ice-sheet is prescribed only over a part of the grid-cells in this area, the rest being ocean. Therefore, the continentality is certainly underestimated when close to the oceanic regions (this is also true for other regions like France, Belgium and the Netherlands).

To evaluate how much of the mismatch between model and data is attributable to this continentality effect and to disentangle it from a more global climatic mismatch, we have conducted a sensitivity experiment with a modified land-sea mask for the ECBilt (atmospheric) model. We arbitrarily assigned all grid-cells containing some land a new value of 95\% land, to artificially increase the continentality of the more inland points. This set-up leads to some inconsistencies between the atmospheric and oceanic models (ECBilt and CLIO); we therefore only integrate it for 100 years to gain an idea of the atmospheric effect without allowing the ocean time to be modified. Results are also presented in Fig. 5, in terms of permafrost. The limit of continuous permafrost is shifted southwards to the north of The Netherlands and across southern Germany and Ireland. It is not in perfect agreement with proxy data (especially with the absence of discontinuous permafrost in France) but is nevertheless improved.

The southernmost winter sea-ice limit is also modified in this "continentality" experiment, from the south of Norway (north of Scotland) to the south of Scotland, along the coast of the United Kingdom. This therefore shows that

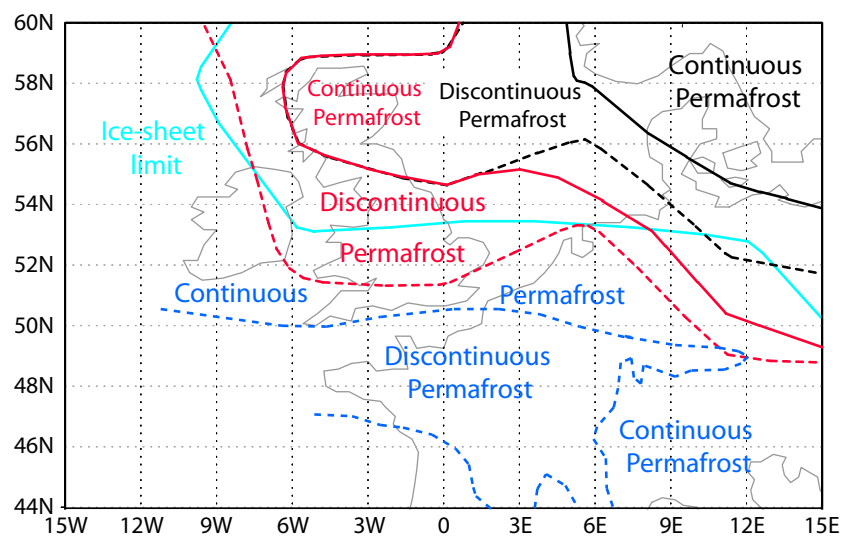

Fig. 5. Permafrost in western Europe: data and model. Limits of permafrost are outlined as follow: continuous black line (respectively dashed black line) is the continuous (respectively non-continuous) permafrost limit for the simulated LGM, continuous red line (resp. dashed red line) is the continuous (resp. noncontinuous) permafrost limit for the "continentality" sensitivity experiment (see text) and continuous dark blue line (resp. dashed dark blue line) is the continuous (respectively discontinuous) permafrost limit inferred from data (Renssen and Vandenberghe, 2003). The continuous light blue line is the limit of the imposed ice-sheet in the atmospheric part of the model.

the relationship between permafrost and sea-ice proposed by Renssen and Vandenberghe (2003) in an atmosphericonly model is also found to some extent in a coupled oceanatmosphere model.

The climate of southern Europe still remains too warm with this drastic set-up, implying that it depends on the simulated sea surface temperatures (which are not much modified in 100 years). We therefore suggest that simulated sea-surface temperatures are too warm in the eastern north Atlantic in our simulated LGM, as discussed hereafter. The method to improve these temperatures is non-trivial, but could encompass the modification of the Mediterranean treatment in the model.

\subsection{Surface ocean}

The goal of this part is to provide a first simple comparison between MARGO data of the glacial surface ocean and our simulated LGM state.

\subsubsection{Sea-ice distribution}

For the Northern Hemisphere, there is a considerable increase of the sea-ice area compared to LH_CTRL, but in a spatially non-homogeneous fashion (see Fig. 6, panels a and b). The summer extent in our simulated LGM is comparable to our present-day winter, with sea-ice covering the Labrador Sea, the Arctic (quasi-continuously) and a small part of the Nordic Seas, almost to the north of Norway. There is also 

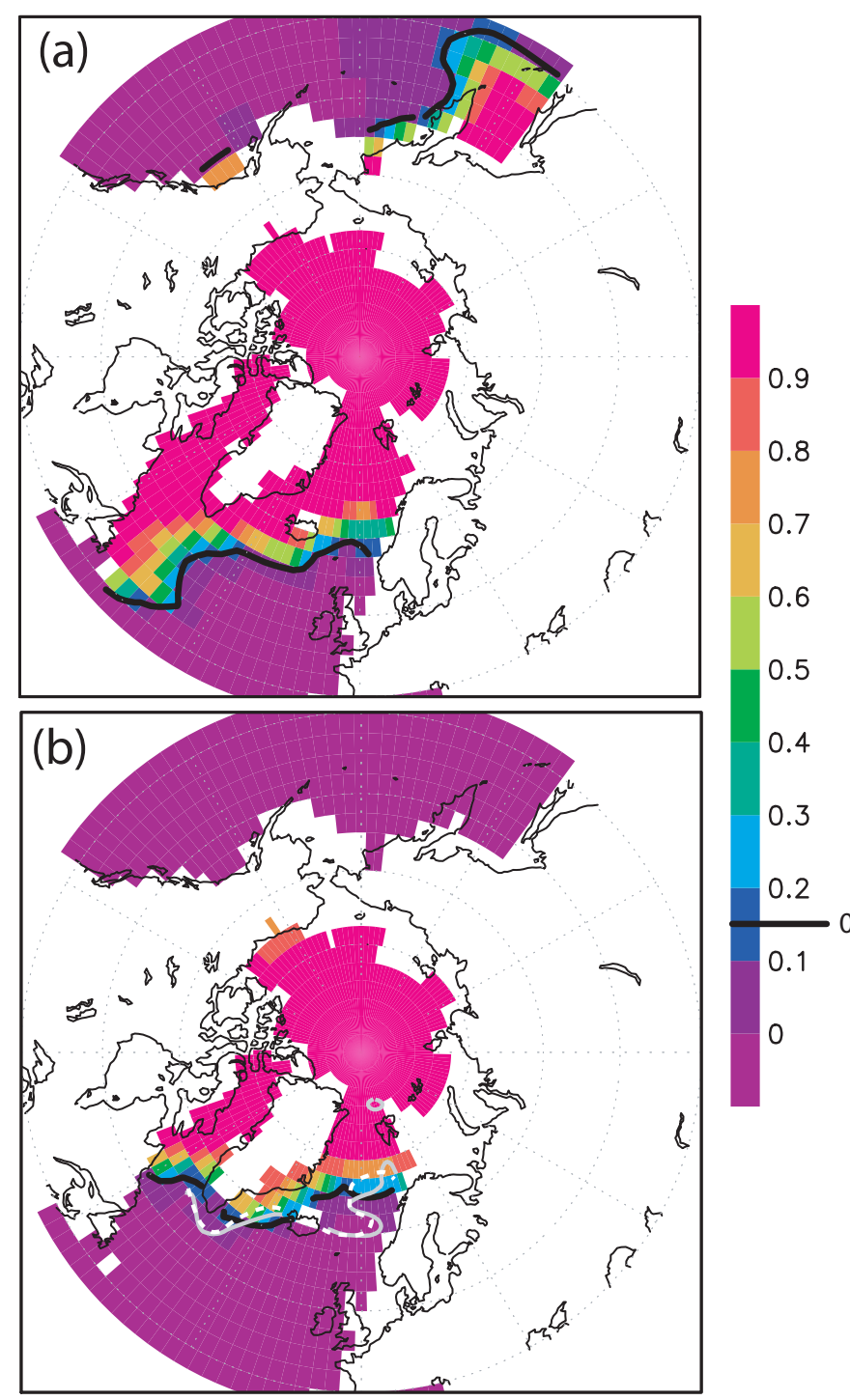
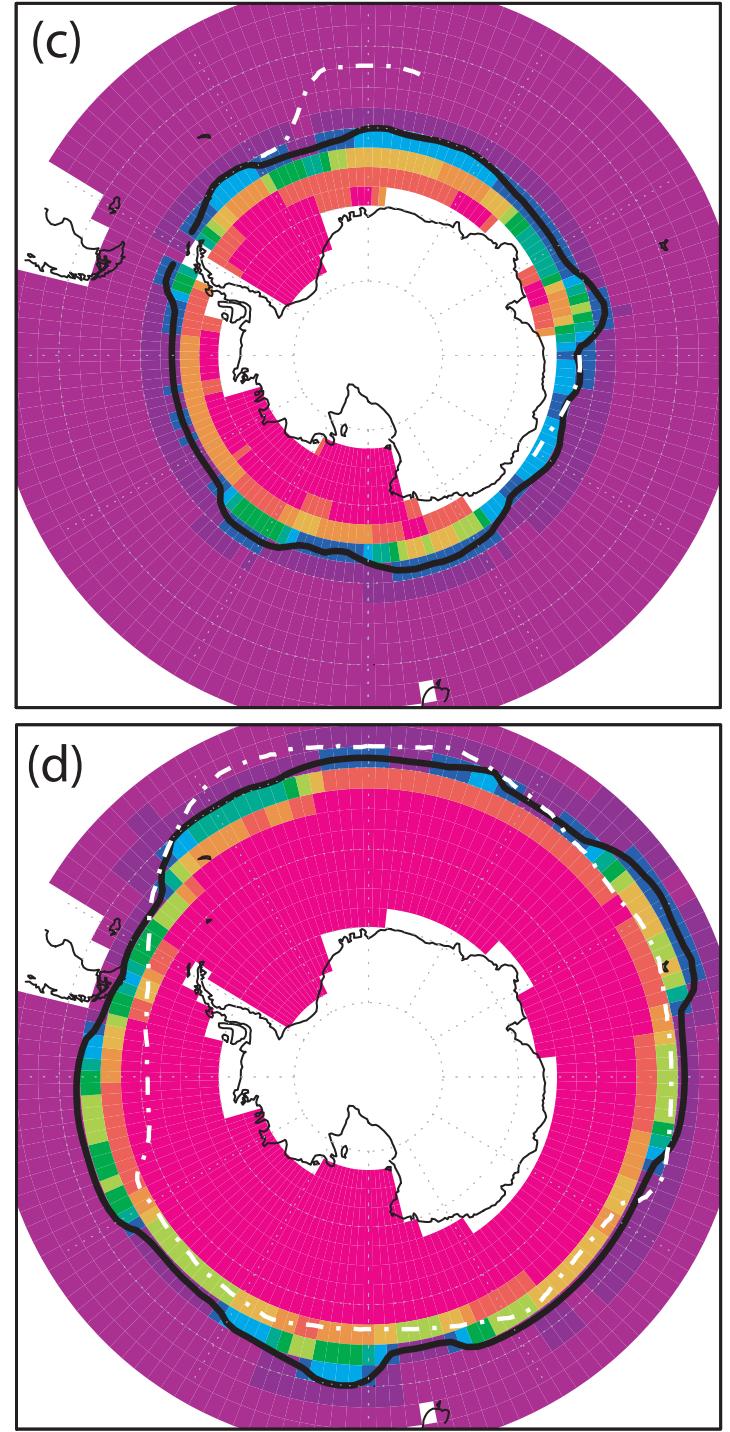

Fig. 6. Sea-ice concentration simulated for the LGM with comparison to MARGO data. Panels (a) and (c) are for the austral summer, (b) and (d) for the boreal summer. Sea-ice concentrations are plotted according to the common colour bar in the centre, with a black contour at $15 \%$, to enable easy sea-ice limit comparison with data of Gersonde et al. (2005); the averaging is performed over the last 200 years of the simulation. On panel (b) (Northern Hemisphere, boreal summer) the dashed white line and the continuous grey line indicate seasonal ice-free conditions from Kucera et al. (2005b). On panels (c) and (d) the dashed-dotted white line shows the summer (c) and winter (d) $15 \%$ sea-ice concentration as from Gersonde et al. (2005).

some sea-ice maintained along the coast of Greenland. If compared with estimations for the limit of seasonal ice-free conditions provided by Kucera et al. (2005b), our simulated sea-ice cover agrees fairly well, except over the eastern Atlantic. In particular, we faithfully reproduce the ice-free conditions prevailing over most of the Nordic Seas and the more extensive southwards extent on the western Atlantic, especially along the coast of Greenland. The simulated boreal winter sea-ice extent shows an important increase of especially along the coast of Newfoundland extending far into the western Atlantic. Conversely, on the eastern side, the winter extension is much more limited, to the south of Iceland and Norway. This shows the effect of the still active north Atlantic drift which, by warming the surface waters, enables ice-free conditions in an important part of the eastern Atlantic. The sea-ice cover is probably somewhat underestimated: given the presence of an ice-sheet covering Scotland and the north of Ireland, it is probable that sea-ice also existed there during winter, at least along the coast. Part of the answer probably lies in the coarse, T21, resolution of the atmospheric model. At this resolution $\left(5.6^{\circ}\right.$ latitude by $5.6^{\circ}$ longitude) the Brittish ice-sheet has a very low altitude and 
the land-sea distribution is poorly represented along continental margins.

For the Southern Hemisphere, there is generally a reasonable agreement between the sea-ice concentrations in our simulated LGM climate and proxy data (Crosta and Pichon, 1998a,b; Gersonde and Zielinski, 2000; Gersonde et al., 2005), as can be seen in Fig. 6, panel (d). Some modeldata discrepancies exist in certain areas. We overestimate slightly the sea-ice cover occurring at the transition between the Pacific and the Atlantic sector in the Southern Ocean, particularly in the southwest of the Magellan archipelago. We also slightly underestimate the sea-ice cover in the southern Atlantic during winter. The simulated sea-ice concentration for the austral summer is consistent with data in the Indian sector, but compares less favorably with data for the Atlantic sector. The model captures fairly well the asymmetry between the Indian sector, where the summer sea-ice extent is comparable to that of today's, and the Atlantic sector, where it is more extensive. However, it fails to reproduce the large extent of sea-ice between $-5^{\circ} \mathrm{E}$ and $5^{\circ} \mathrm{W}$. There are two options to account for this discrepancy: either the limit derived from the diatoms is for the particularly cold summers or there is a spreading of sea-ice which is not represented in the model. The former option, though the sea-ice extent is denoted as "sporadic" (Gersonde et al., 2005), seems however not to be the most probable: Gersonde et al. (2003) rather point to a local expansion due to specific Weddell Sea dynamics, which, we believe, are not represented in the CLIO model.

\subsubsection{Sea surface temperatures}

Here we provide an outline of the data-model comparison between our LOVECLIM results and MARGO data for the annual mean SST and LGM to LH difference, to better position the state of the simulated LGM climate. The MARGO project released an extensive coverage of Sea Surface Temperature (SST) estimates for the LGM for a wide range of proxies. It is beyond the scope of the present study to compare in detail the results obtained here with the MARGO database, especially taking into account that not only annual average SSTs are provided, but also in most cases those for summer and winter (see Kucera et al., 2005a, and companion papers). We will follow an approach comparing different regions: Indian Ocean and Australian margins, Pacific, Southern and Atlantic Ocean.

For the Indian Ocean and the Australian margins, the model indicates differences of -1 to $-2^{\circ} \mathrm{C}$ relatively homogeneously, in good agreement with proxy data (Barrows and Juggins, 2005). Indeed, in terms of mean annual SST anomalies between LGM and present-day, proxy data broadly show a general moderate cooling of the equatorial regions of 0 to $3^{\circ} \mathrm{C}$. Some data points for the equatorial Indian ocean even indicate no changes or a small warming. In the tropical regions, the Gulf of Bengal and the Arabian Sea show a very
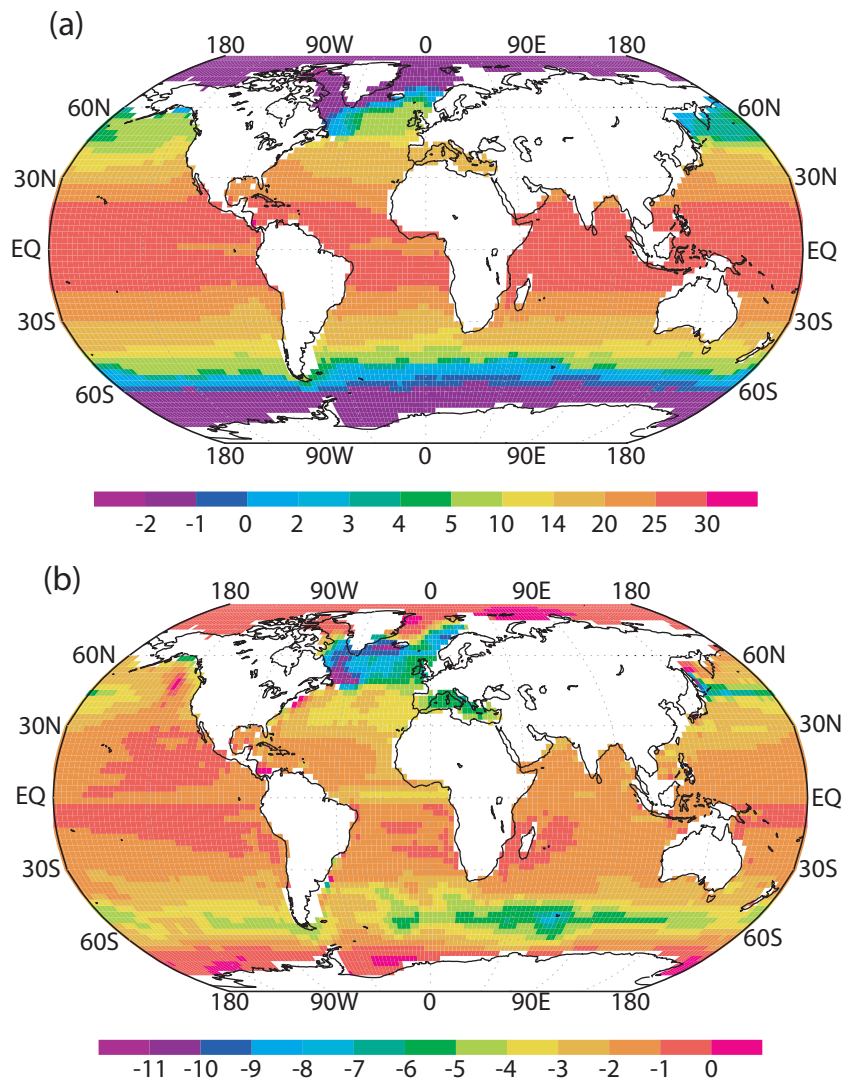

Fig. 7. (a) Sea Surface Temperatures at the LGM $\left({ }^{\circ} \mathrm{C}\right)$ (b) LGMLH_CTRL Sea Surface Temperature differences $\left({ }^{\circ} \mathrm{C}\right)$. Both panels are averages over the last 200 years of the simulations.

small cooling, with no change or less than $1^{\circ} \mathrm{C}$ cooling. This feature is not seen in our simulation, which yields a cooling by 1 to $2^{\circ} \mathrm{C}$, and even some greater cooling along the coast of India. The reason for this mismatch is not clear, and would need to be further investigated. Changes are of greater magnitude in proxy data to the south, with cooling of 3 to $5^{\circ} \mathrm{C}$ at $30-35^{\circ} \mathrm{S}$ south of Madagascar.

This is also more or less the case in the model, which simulates cooling of 2 to $4^{\circ} \mathrm{C}$ in the same area. Around $40^{\circ} \mathrm{S}$, eastward from the Kerguelens, data show a more pronounced cooling, between 3 and $5^{\circ} \mathrm{C}$; this feature is also well marked in the simulated LGM where cooling reaches 3 to $5^{\circ} \mathrm{C}$. In this region, we find the greatest simulated cooling in the Southern Hemisphere ocean, with about $8^{\circ} \mathrm{C}$. These huge changes are linked to the northwards migration of the Polar Front and of the Antarctic sea-ice margin, which promote the northward expansion of colder waters. Finally, the biggest changes occur in the Pacific Ocean, east of Australia, where there is a cooling of 3 to $5^{\circ} \mathrm{C}$ at $30^{\circ} \mathrm{S}$, and up to $7-8^{\circ} \mathrm{C}$ over the Campbell Plateau, southeast of New Zeeland. These changes are qualitatively well represented in the model which simulates a -3 to $-4^{\circ} \mathrm{C}$ change off the eastern coast of Australia, and 4 to $5^{\circ} \mathrm{C}$ cooling at the Campbell Plateau. However, we do 
not reach the extreme cold shown by proxy data in the latter region.

For the nearby Pacific, data are more sparse, but still show some patterns which we can compare to our simulation (Kucera et al., 2005b). The equatorial Pacific, as reconstructed, shows little changes (assigned as -1 to $1^{\circ} \mathrm{C}$ ), but with slightly cooler temperatures on the South American side $\left(-1\right.$ to $\left.-3^{\circ} \mathrm{C}\right)$. This is also the case in our simulation, which presents an homogeneous cooling of 0 to $1^{\circ} \mathrm{C}$ in the equatorial region, with the exception of slightly cooler temperatures along the south American coast $\left(-1\right.$ to $\left.-2^{\circ} \mathrm{C}\right)$. We simulate 1 to $2^{\circ} \mathrm{C}$ cooling in the Pacific warm pool, quite in line with independent proxy data estimates (Chen et al., 2005). At $30^{\circ} \mathrm{N}$, the reconstructions show no clear signal (ranging from +1 to $-3^{\circ} \mathrm{C}$ ) to compare to our simulated 2 to $4^{\circ} \mathrm{C}$ cooling. Northeast of Japan, around $50^{\circ} \mathrm{N}$, data show an LGM to LH_CTRL cooling of about 1 to $3^{\circ} \mathrm{C}$ or even more; our simulation compares relatively well with a -2 to $-4^{\circ} \mathrm{C}$ changes in this region. Finally, our simulation does not reproduce the cooling of more than $3^{\circ} \mathrm{C}$ seen in proxy data for the American coast at $40^{\circ} \mathrm{N}$. In particular, proxy data show an annual mean temperature of about $8^{\circ} \mathrm{C}$ at this location whereas the model simulates an annual temperature of about 12 to $14^{\circ} \mathrm{C}$, a temperature barely reached in the proxy data $10^{\circ}$ westward. Two possibilities could be further investigated: the first would be the role of coastal effects, the second of the extension of sea-ice in the northeastern Pacific (non-existent in our simulations, see Fig. 6) both in relationship with the evolution of the California current.

Around Antarctica, our model simulates an important cooling, with an annular pattern around the continent, quite in line with proxy data of Gersonde et al. (2005). This seems a logical counterpart of the good ability of the model to simulate the sea-ice in this region.

For the Atlantic, our simulations produce general changes quite consistent with proxy data (Pflaumann et al., 2003; Kucera et al., 2005b) for equatorial regions $\left(-2\right.$ to $-4^{\circ} \mathrm{C}$ in both data and model $)$ and the $20^{\circ} \mathrm{N}$ band $\left(0\right.$ to $-1^{\circ} \mathrm{C}$ in data vs. -1 to $-2^{\circ} \mathrm{C}$ in the model. The agreement holds for the mid-latitude Atlantic further to the north where the model simulates a cooling from $2^{\circ} \mathrm{C}$ at $30^{\circ} \mathrm{N}$ to $4^{\circ} \mathrm{C}$ around $40^{\circ} \mathrm{N}$ and proxy data suggest a cooling of -1 to $-4^{\circ} \mathrm{C}$. There is however an important mismatch in the more northern regions: the model simulates the maximum cooling along the American coast whereas this is found off the coast of Ireland according to proxy data. This mismatch may be due to model poor representation of the northern Atlantic gyre circulation in our model, or the treatment of the Mediterranean Sea, as discussed below. Model-data discrepancies in this area are a common feature already recognised in several coupled models (Kageyama et al., 2006).

In the Mediterranean sea, although the resolution of the model is too low to simulate the dynamics occurring here in detail, we obtain a broad agreement with proxy data (Hayes et al., 2005). We simulate anomalies ranging from -5 to $-6^{\circ} \mathrm{C}$ in the western part $\left(-6^{\circ} \mathrm{C}\right.$ in data) to -3 to $-4^{\circ} \mathrm{C}$ in the eastern part ( -2 to $-3^{\circ} \mathrm{C}$ in data).

To summarise, generally our simulated SSTs are consistent with data in most areas. We have discussed some mismatches in specific regions. The causes of these mismatches may be diverse, but several seem to be linked to the displacement of oceanic fronts or local currents, features difficult to simulate with accuracy. The precise cause of these mismatches should be further investigated.

\subsection{Subsurface northern Atlantic and Nordic seas}

Given the importance of the north Atlantic Ocean and Arctic Seas in producing part of the deep waters of the world ocean, we perform here a more detailed comparison between the modeled and proxy-based subsurface temperatures (Meland et al., 2005), as shown in Fig. 8. Our results (panel a) are given on the same projection and scale for ease of comparison with temperatures estimates from $\delta^{18} \mathrm{O}$ (see panel b, reproduced from Meland et al., 2005).

Data presented show a fairly strong east-west gradient, from quite high temperatures $\left(8\right.$ to $\left.9^{\circ} \mathrm{C}\right)$ off the coast of France to much lower temperatures $\left(1\right.$ to $\left.3^{\circ} \mathrm{C}\right)$ south of Greenland at the same latitude. This gradient is present all the way to Svalbard, but weakens to a $3^{\circ} \mathrm{C}$ difference between east and west along Iceland, similar at the south of the Svalbard. In our simulated LGM, such a gradient also exists (linked to the presence of the (glacial) north Atlantic Drift) but it is of correct magnitude only around the north of Ireland $\left(6^{\circ} \mathrm{C}\right.$ difference from $9^{\circ} \mathrm{C}$ on the east coast to $3^{\circ} \mathrm{C}$ to the west). South of about $50^{\circ} \mathrm{N}$, the model shows fairly homogeneous relatively high annual temperature (more than $10^{\circ} \mathrm{C}$ ). These waters of quite high temperatures entering the eastern Atlantic originate from a mixture of lower latitude Atlantic waters and Mediterranean Sea water of higher temperatures. Due to the relatively coarse resolution of the model, the strait of Gibraltar is much wider than in reality. Therefore, the exchange seems to be too important at the LGM between the Mediterranean Sea and the Atlantic Ocean. This is likely to be the source of the 2 to $3^{\circ} \mathrm{C}$ overestimation off the coast of Ireland.

Northwards, the model results are fairly comparable to data, with only about $1{ }^{\circ} \mathrm{C}$ difference, and a very similar eastwest pattern, indicating that we capture correctly the entrance of north Atlantic waters in the Nordic Seas. The influence of the north Atlantic waters entering the Nordic seas extends up to the Svalbard as can be inferred from the flow vectors (not shown), as is seen in data. For the Nordic seas, our simulated annual temperatures are more homogeneous than those seen in data, with slightly too cold temperatures at the northern tip of Norway. This seems to be linked to a small regional overestimation of the sea-ice cover in that area (see Fig. 6). This explains that the influence of the North Atlantic waters entering the Nordic Seas is less prominent from the temperature field than in data. Otherwise, the annual temperature in 
the Nordic Seas is fairly well represented, with waters close to the freezing point along the western coast of Greenland, suggesting perennial sea-ice cover.

To summarise, the model-data comparison shows that LOVECLIM simulates reasonable annual mean LGM temperatures in the northern Atlantic and Nordic Seas, with a more or less correct east-west gradient. A discrepancy is found in the absolute value south of $55^{\circ} \mathrm{N}$, probably linked to the representation of the Mediterranean outflow in a relatively coarse resolution model. This latter question needs to be re-addressed in future studies.

\subsection{Deep ocean circulation}

In this sub-section, we review the LGM state as simulated by the LOVECLIM model for the oceanic circulation with respect to the available proxy data. Different types of proxies are usually used as constraints with the view of determining the palaeoceanographic state of the LGM.

Our simulated LGM state includes three source locations for deep waters: two in the Northern Hemisphere and one in the Southern Hemisphere. As discussed in Sect. 3.4, we find in the Northern Hemisphere a main site south of Iceland, and a secondary location in the Nordic Seas. In LH_CTRL, the main site for NADW formation is in the Nordic Seas. The simulated southward shift of the main northern convection site to a location south of Iceland is consistent with proxy data (Labeyrie et al., 1992; Oppo and Lehman, 1993). Proxy evidence also exists for active deep water formation in the Nordic Seas (Dokken and Jansen, 1999) during the LGM, in line with our findings.

A tracer which is often used to characterise oceanic water masses in the past is the $\delta^{13} \mathrm{C}$ measured in foraminifera tests (Duplessy et al., 1988, for example), used to distinguish between ventilated and less-ventilated water masses. A feature present in any reconstruction of the glacial $\delta^{13} \mathrm{C}$ is the very strong vertical gradient at $2500 \mathrm{~m}$ dividing the Atlantic between an upper well-ventilated water mass and a lower, much less-ventilated, water mass. The current interpretation of this gradient is the existence of two water masses in the Atlantic: the upper one is attributed to the GNAIW (Glacial North Atlantic Intermediate Water), forming south of Iceland, and the lower one to the GAABW (Glacial Antarctic Bottom Water) assumed to form along the Antarctic coast. Thus, defining the $\delta^{13} \mathrm{C}$ end-members of the (supposed) main water masses allows to evaluate with some accuracy (Duplessy et al., 1988; Curry and Oppo, 2005) the degree of mixing between northern and southern water masses. For example, in Curry and Oppo (2005), a ratio of $50 \%$ of GAABW to $50 \%$ of GNAIW is found in the North Atlantic at $3100 \mathrm{~m}$ and $30^{\circ} \mathrm{N}$ ).

In our LGM simulation, we have three instead of two deep water masses in the Atlantic. We can identify GNAIW that is formed at the main deep convection site south of Iceland, and a second water mass that is formed in the Nordic Seas. This latter water mass is denser than the modelled GNAIW; thus
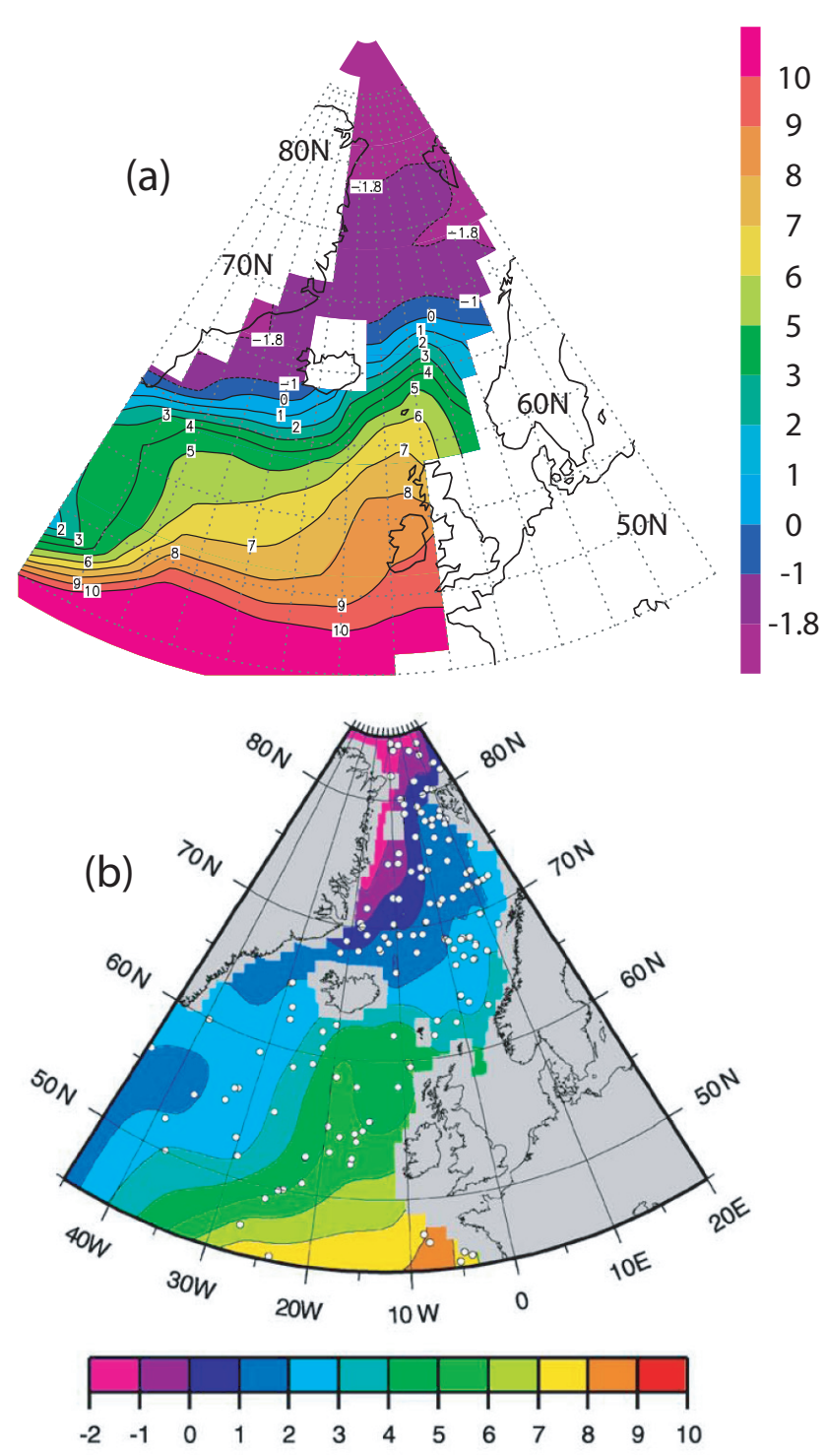

Fig. 8. Model-data comparison: north Atlantic and Nordic Seas subsurface temperatures. Panel (a) shows the model annual mean temperature $\left({ }^{\circ} \mathrm{C}\right.$ ) between 50 and $150 \mathrm{~m}$ depth (averaged over 200 years). Panel (b) is an $\delta^{18} \mathrm{O}$-based temperature estimation $\left({ }^{\circ} \mathrm{C}\right) \mathrm{re}$ produced from Meland et al. (2005) (with permission from Elsevier).

we will refer to it as GNADW (Glacial North Atlantic Deep Water). The third water mass is GAABW, with a source in the Southern Ocean. To compare our simulation with $\delta^{13} \mathrm{C}$ data (Curry and Oppo, 2005), we therefore need to consider three end-members. Regrettably, we do not simulate explicitly the $\delta^{13} \mathrm{C}$ in our model, so we are unable to precisely assess its distribution. However, some interesting features should be pointed out. Regarding density properties, the two water masses identified as GNADW and GAABW have characteristics very close to each other (GNADW is warmer and saltier than GAABW, but their densities are similar). In our simulation, both GNADW and GAABW are formed 
in sea-ice covered regions, implying that these deep water masses are not well ventilated. Therefore, we would expect the mixture of the two water masses to have $\delta^{13} \mathrm{C}$ values depleted with respect to GNAIW. The exact values for each of the end-members depend on the $\delta^{13} \mathrm{C}$ content of the waters from which they are formed. However, it seems plausible that the simulated GNADW and GAABW have a $\delta^{13} \mathrm{C}$ signature close to each other in the deep north Atlantic. Therefore, if this line of reasoning is followed, the obtained ocean would indeed be partitioned between a deep water mass (being a mix between the GNADW and the GAABW, depending on the location) and an upper ocean one (GNAIW). Evidences of $\delta^{13} \mathrm{C}$ data (Curry and Oppo, 2005), showing a very depleted deep water mass (GAABW) entering the south Atlantic (values around -0.8 per mil at $3000 \mathrm{~m}$ depth) evolving to a less depleted deep water mass in the northern Atlantic (values around 0.0 per mil at $3000 \mathrm{~m}$ depth) are consistent with this hypothesis of mixing betwee $\mathrm{n}$ GAABW and GNADW masses.

Conversely, $\mathrm{Pa} / \mathrm{Th}$ ratios measured in the shells of foraminifera, used as a proxy for advection, are linked directly to changes in oceanic circulation. The $\mathrm{Pa} / \mathrm{Th}$ is a Lagrangian tracer and thus integrates changes in transport of water from the source (sinking regions) to the site where it is measured. Therefore, its recorded variation over time at the site may depend on the global circulation (on average, less water advected in the whole north Atlantic and over the site) or a more local change at the site, being more slowly ventilated whereas some regions are more ventilated. From the three different studies addressing changes in oceanic circulation with the $\mathrm{Pa} / \mathrm{Th}$, one study (Yu et al., 1996) was aimed at a basin-scale reconstruction of the LGM oceanic circulation. They showed that the data obtained were consistent with a strength of the glacial Atlantic meridional overturning similar to that of the present-day. In a later reassessment of the same data with the aid of a model, Marchal et al. (2000) showed that available $\mathrm{Pa} / \mathrm{Th}$ data is also consistent with a reduction of the strength of the circulation by up to $30 \%$. Finally two recent studies addressed the temporal variation of the thermohaline circulation in the western (McManus et al., 2004) and eastern (Gherardi et al., 2005) Atlantic basins over the last deglaciation. The first one showed that at a depth of $4.5 \mathrm{~km}$ in the west Atlantic, the vertically integrated oceanic transport was reduced by $30 \%$ at the LGM with respect to present-day. The second one deduced that the vertically integrated oceanic transport in the eastern Atlantic at a depth of $3.1 \mathrm{~km}$ was enhanced at the same time. This indicates that: a) the thermohaline circulation was stronger in the first $3 \mathrm{~km}$ of the ocean, a feature compatible with the circulation we obtain in the model and b) that the deep circulation between 3 and $4.5 \mathrm{~km}$ was likely to be very sluggish between 30 and $40^{\circ} \mathrm{N}$, a feature also consistent with our simulated meridional overturning circulation (see Fig. 3). Therefore, although our oceanic circulation pattern disagrees with the current view of the LGM circulation, it appears to be quite consistent with available $\mathrm{Pa} / \mathrm{Th}$ data constraining the LGM circulation.

The evaluation of modelled LGM deep ocean temperatures and salinities is hampered by the scarcity of proxy-based estimates. However, a few data have been published, based on pore waters measurements in a few sediment cores (Adkins et al., 2002). Table 2 shows a comparison between the points measured by Adkins et al. (2002) and results from our LGM simulation. In proxy data, glacial salinity and temperatures decrease from very high salinities (37.08 permil) and cold waters $\left(-1.3^{\circ} \mathrm{C}\right)$ in the Southern Ocean to lower salinities and temperatures toward the North Atlantic Ocean. Such changes can be interpreted as the mixing between a cold and extremely saline Southern Ocean water mass (GAABW) and a less saline and extremely cold North Atlantic deep water mass (GNADW).

In the model, we obtain cold Southern Ocean waters (e.g. $-1.41^{\circ} \mathrm{C}$ in the Pacific sector) but a much warmer deep north Atlantic, probably indicating too strong an influence of deep waters formed south of Iceland (especially at $2 \mathrm{~km}$ depth). Two hypotheses can be proposed to solve this discrepancy: either the formation of GNAIW should be colder an a seasonal basis or this water mass should be replaced by another one (GAABW or GNADW). We however consider this latter option unlikely, as data suggest that the upper water mass is present at $2 \mathrm{~km}$ depth. Conversely, we simulate relatively correctly the salinity of the northern water mass, but largely underestimate that of the southern water mass. The reasons for these discrepancies are not easy to tackle. This might be due to some extent to the spatial resolution of the model. Indeed, processes that account for deep water formation under sea-ice (both in the Northern Hemisphere for GNADW and in the Southern Hemisphere for GAABW) are by nature small-scale phenomena. They are therefore difficult to represent in a relatively coarse resolution model. Another reason linked to the ocean model resolution is the conservation of the properties of water masses along the advective path. In a relatively coarse resolution model, the water masses generally tend to mix to a larger extent in comparison with higher resolution models. Keeping colder, saltier waters in the deep ocean might therefore be more problematic when the resolution is coarser. A way to test this would be to run the model with the oceanic module at a higher spatial resolution.

We can therefore state that, in our model, deep waters are not formed with the correct temperatures and salinities. The densities we simulate are similar in the north and in the south (difference of only $+0.06 \mathrm{~kg} \mathrm{~m}^{-3}$, in $\sigma_{1}$ ) whereas they are substantially different in proxy data (difference of about $-1 \mathrm{~kg} \mathrm{~m}^{-3}$, in $\sigma_{1}$ ). This might indicate that there was more presence of GAABW in the north Atlantic in the LGM (southern source waters being much denser than northern ones), but the very different characteristics of the two extremes sites measured (ODP 1063 and 1093) shows that the existence of two different deep water masses filling in the Atlantic is a viable alternative to the prevailing view. 
Table 2. Temperature and salinities of the LGM deep water masses: comparison between Adkins et al. (2002) and our simulated ocean. 1 permil has been added to the modelled salinities to account for the glacial lowering of sea-level.

\begin{tabular}{lccccccc}
\hline Location & ODP Site & latitude $\left({ }^{\circ} \mathrm{N}\right)$ & depth $(\mathrm{m})$ & $\theta\left({ }^{\circ} \mathrm{C}\right)$ & $\mathrm{S}$ (permil) & $\theta_{\text {model }}\left({ }^{\circ} \mathrm{C}\right)$ & $\mathrm{S}_{\text {model }}($ permil $)$ \\
\hline N. Atlantic & 981 & 55 & 2184 & $-1.2 \pm 0.5$ & 36.10 & 1.85 & 36.41 \\
N. Atlantic & 1063 & 34 & 4584 & $-2.2 \pm 0.5$ & 35.83 & 0.9 & 36.36 \\
S. Ocean & 1093 & -41 & 3626 & $-1.3 \pm 0.5$ & 37.08 & -0.31 & 36.19 \\
S. Pacific & 1123 & -50 & 3290 & $-1.2 \pm 0.5$ & 36.19 & -1.41 & 36.14 \\
\hline
\end{tabular}

Table 3. Sensitivity of the oceanic circulation to different choices of parameters. First line of the table gives the control LGM state, the rest shows variations with respect to this state following the experiment proposed. The "GIN Seas Overt." is the part of the deep water masses formed in the Greenland-Iceland-Norwegian (GIN) seas, "NADW overt." is the maximum overturning in the north Atlantic, "AABW inflow" denotes the rate of inflow of the deep Antarctic mass in the Atlantic, "AABW prod." is the maximum overturning in the Southern Ocean. The label "w.e." stands for "weak effect" and the label "n.e." for "no effect". "w.e." is attributed when the signal obtained is less than the natural variability of the model (about $1 \mathrm{~Sv}$, on an interannual basis). Further details of each experiment are discussed in the text.

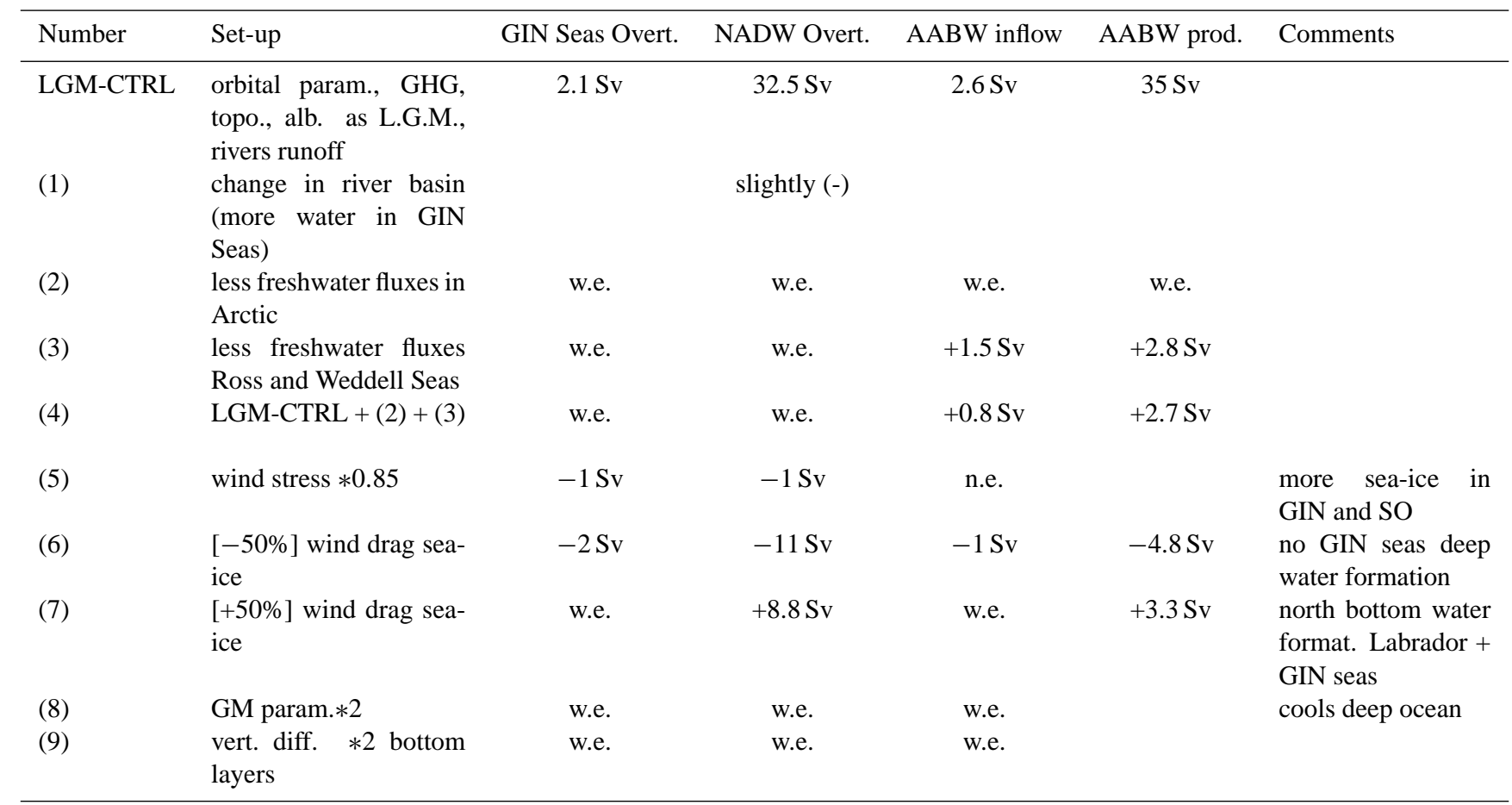

To conclude this proxy data-model comparison we can state that although the characteristics of the deep water masses we obtain are substantially different from data inferences (northern source being too warm and southern source being not saline enough) the circulation pattern is broadly consistent with $\delta^{13} \mathrm{C}$ and $\mathrm{Pa} / \mathrm{Th}$ data.

\section{Sensitivity experiments}

5.1 Sensitivity of the simulated LGM to various parameters values

To explore the stability of the oceanic circulation obtained, we have performed an ensemble of sensitivity studies of the LGM state to different parameters intrinsic to the model (see Table 3), or dependent on the LGM set-up chosen. For each parameter tested, we restarted from the LGM state and ran the model with the new parameters' value until equilibrium was reached (usually 1000 or 1500 years, except for runs 
with importantly modified deep circulation, which need to be run for 3000 years). As we performed these experiments to determine whether the simulated LGM circulation, with three deep water masses, was a stable feature in the LOVECLIM model or only a stable state for the current set of parameters, the results are expressed in terms of thermohaline circulation intensities for the north Atlantic deep water mass and the Southern Ocean deep water mass.

Generally, we performed three types of sensitivity experiments: those in which we modified the surface water budget by changing the partitioning of the water coming from land (snow melting, rivers and calving: $2,3,4$ ), those in which the effect of the wind on the sea or sea-ice was modified $(5,6,7)$ and those for which an intrinsic oceanic parameter value was adjusted $(8,9,10)$.

In the modified freshwater budget experiments, we changed the outlet for the river runoff and calving to increase the input of water to the GIN seas (1), displaced all Arctic outlets into the north Atlantic, south of $50^{\circ} \mathrm{N},(2)$ and modified the redistribution of calving from Antarctica from the border of the continent to 60 to $50^{\circ} \mathrm{S}(3)$. Results obtained for these three experiments show that the LGM circulation is not sensitive to these small changes in the freshwater budget, the maximum effect obtained (exp. 3) being an $1.5 \mathrm{~Sv}$ increase in the flow of southern deep water mass entering the Atlantic basin (in response to a slight increase in salinity of these waters, consistent with the discussion of Sect. 4.5).

In the experiments with modified wind effect on the surface, we integrated the model with three different set-ups: one with a modified drag coefficient $(85 \%$ of the control value) for the wind on the surface, both for ocean and sea-ice (5), two where we applied drastic changes on the wind-drag coefficient with respect to sea-ice (6 and 7 with respectively 150 and $50 \%$ of the control value). These experiments were chosen for two reasons: a) the CLIO ocean model is known to be sensitive to the value of the drag coefficient chosen, b) the sea-ice export is controlled by the wind on sea-ice; an easy way of testing different partitioning of the sea-ice is to modify the effectiveness of wind on the latter. In experiment (5) we obtained very little effect on the water masses from the $15 \%$ reduction in the wind-drag coefficient. As expected, there is more sea-ice in the GIN seas, as it is less exported. This larger sea-ice extent promotes a slightly reduced deep water formation in the GIN seas, caused by both the insulation effect of the sea-ice which prevents the cooling of the surface ocean and the reduced salinity increase linked to the formation of sea-ice. The same effect is obtained in experiment (6), in which a drastic reduction of the wind-drag coefficient on sea-ice provokes a quasi-cessation of deep water formation in the GIN seas. This is due to the extremely reduced export of sea-ice thereby considerably reducing the meridional overturning both for the north Atlantic deep water mass and for the southern deep water mass. The opposite is also valid for experiment (7) where the wind-drag is increased: we obtain an increase of the deep water formation, with a shift in the northern part from the south of Iceland to the Nordic and Labrador Seas (present-day like mode of deep water formation). It should be noted however that a) the effect of wind drag changes on the thermohaline circulation is not linear b) there is no change in the relative proportion of our two water masses in the Atlantic.

Finally we also changed some classical intrinsic parameters in the ocean: the Gent-McWilliam coefficient in the isopycnal mixing scheme of the CLIO model (Gent and Mcwilliams, 1990; Goosse and Fichefet, 1999) (8, 200\% of the control value) and the background diffusivity in the deep ocean $(9,200 \%$ of the control value). We modified these parameters because they have been shown to have an effect on both water properties and on the strength of the overturning.

As sensitivity experiments, it is worthwhile to consider the simulated ocean circulations in the light of the previously discussed comparison with proxy data from the Atlantic Ocean. In a majority of the sensitivity experiments $(1,2,5,8$ and 9), the characteristics of our LGM ocean circulation in the Atlantic (Table 3) do not change substantially. Only the experiment with a $50 \%$ reduction in the wind drag on sea ice (exp. 6) produces a significant reduction in the strength of the NADW overturning cell (by $11 \mathrm{~Sv}$ ) which would be in better agreement with the current view of the LGM ocean state. However, in this experiment the inflow of AABW is also reduced (by $4.8 \mathrm{~Sv}$ ), while it should increase to match this current LGM view. The AABW inflow does increase in the sensitivity experiments with a reduced freshwater flux into the Southern Ocean (exp. 2 and 3), but here the NADW overturning strength remains unaffected. In short, none of the sensitivity experiments produces an overturning circulation in the Atlantic Ocean that is in full agreement with the generally accepted view for the LGM.

To summarise, we can say that none of the parameter modification suggested here could enable a drastic change in the balance between northern and southern deep water masses. Exp. (3) confirms that an increase in salinity of the southern deep water mass tends to increase its presence in the deep Atlantic. This ensemble of tests also shows that the export of sea-ice is an important process in governing the absolute strength of deep water formation in the model $(6,7)$.

\section{Summary and conclusions}

In this study, we have presented the LGM climate simulated by the LOVECLIM Earth system model, from atmospheric, oceanic and vegetation points of view. Generally, the climate simulated was found to be in reasonable agreement with available data for the surface, both from the oceanic and estimated biomes distribution. Regional discrepancies were found for which we suggested lines of further investigations. Conversely, the deep ocean circulation was found to be at odds with the generally accepted view for the LGM based on proxy data. According to this view, the overturning in 


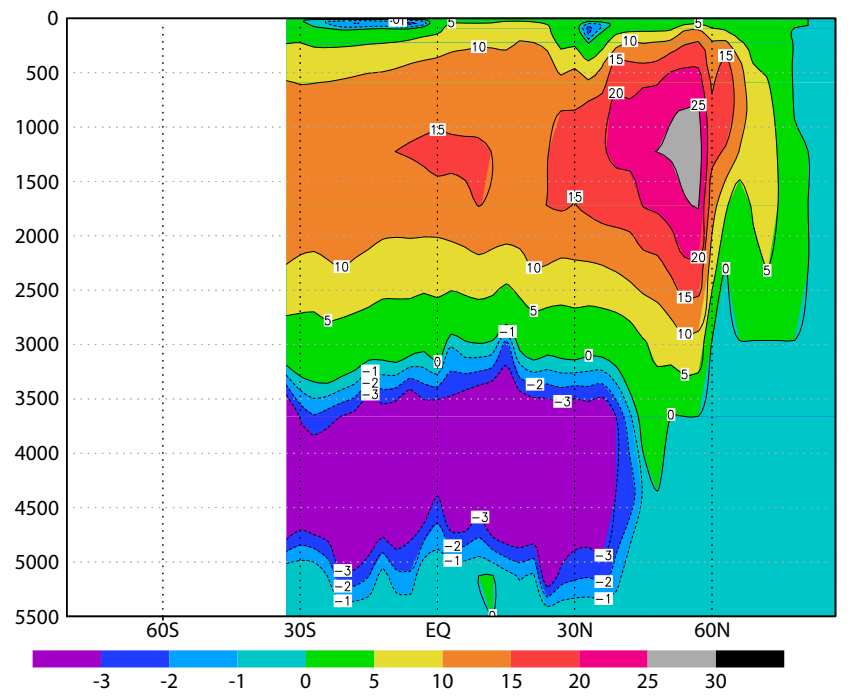

Fig. A1 LH_CTRL meridional overturning stream function in the Atlantic ocean. Contours are in Sverdrup, positive (respectively negative) values denote clockwise (resp. counterclockwise) flow. Figure shows the average over the last 200 years of the control simulation.

the Atlantic Ocean was weaker than today, with a shallower North Atlantic deep water mass positioned over a denser and more dominant Antarctic water mass. Our LGM simulation shows a stronger overturning circulation than for the Late Holocene and three deep water masses in the Atlantic Ocean, viz. GNAIW formed south of Iceland, GNADW formed in the Nordic Seas and GAABW formed in the Southern Ocean.

Although our LGM ocean circulation contradicts the prevailing view, we have argued that our result is not necessarily inconsistent with proxy data. In our view, an alternative and viable interpretation of available $\delta^{13} \mathrm{C}$ values and $\mathrm{Pa} / \mathrm{Th}$ ratios is consistent with an enhanced LGM overturning and three deep water masses in the Atlantic Ocean, as suggested by our simulation. We therefore argue that our simulated LGM ocean circulation deserves consideration as an alternative to the prevailing view.

To evaluate the robustness of our result, we have also presented a sensitivity study to quantify which parameters in the model set-up could be comprehensively tuned to obtain a different deep ocean water mass distribution. Although we found that some of the parameters tested are effective in modifying the strength of the simulated meridional overturning circulation, we also found that none of them enabled us to modify drastically the distribution between the deep Atlantic water mass and the intermediate one.

An obvious and necessary future step is to include tracers such as $\delta^{13} \mathrm{C}$ and $\mathrm{Pa} / \mathrm{Th}$ in our model and to repeat the LGM simulation to see if our deep ocean circulation is indeed consistent with proxy data. In addition, such LGM simulations including tracers should be performed with other coupled cli- mate models. Furthermore, the data community could help to resolve this issue by reducing the considerable uncertainties in the proxies for deep ocean circulation.

\section{Appendix A}

\section{Meridional Overturning in the LH_CTRL experiment}

Figure A1 shows the meridional overturning stream function in the Atlantic using the same scale as in Fig. 3 to allow for an easy comparison.

Acknowledgements. This work is part of the RAPID project ORMEN: The impact of changing freshwater flows on the thermohaline circulation and European climate analysis and modeling of the last deglaciation. D. M. Roche and H. Renssen are supported by the Netherlands Organization for Scientific Research (NWO). H. Goosse is Research Associate with the Fonds National de la Recherche Scientifique (Belgium) and is supported by the Belgian Federal Science Policy Office.

We are thankful to J. Jongma for discussion of icebergs paths at the LGM. Coauthors are listed alphabetically.

Figure $8 \mathrm{~b}$ in the present study is reprinted from Quaternary Science Reviews, 24,Meland, M. Y., Jansen, E., and Elderfield, H.: Constraints on SST estimates for the northern North Atlantic/Nordic Seas during the LGM, Pages No. 835-852, (C) 2004, with permission from Elsevier.

Edited by: J. Hargreaves

\section{References}

Adkins, J., McIntyre, K., and Shrag, D.: The Salinity, Temperature, and $\delta^{18} \mathrm{O}$ of the Glacial Deep Ocean, Science, 298, 1769-1773, 2002.

Alley, R.: The Younger Dryas cold interval as viewed from central Greenland, Quat. Sci. Rev., 16, 213-226, 2000.

Barrows, T. and Juggins, S.: Sea-surface temperatures around the Australian margin and Indian Ocean during the Last Glacial Maximum, Quat. Sci. Rev., 24, 1017-1047, doi:10.1016/j. quascirev.2004.07.020, 2005.

Basile, I., Grousset, F. E., Revel, M., Petit, J. R., Biscaye, P. E., and Barkov, N. I.: Patagonian origin of glacial dust deposited in East Antarctica (Vostok and Dome C) during glacial stages 2, 4 and 6, Earth Planet. Sci. Lett., 146, 573-589, 1997.

Berger, A. and Loutre, M.: Astronomical solutions for paleoclimate studies over the last 3 millions years, Earth Planet. Sci. Lett., 111, 369-382, 1992.

Bigelow, N. H., Brubaker, L. B., Edwards, M. E., Harrison, S. P., Prentice, C., Anderson, P. M., Andreev, A. A., Bartlein, P. J., Christensen, T. R., Cramer, W., Kaplan, J. O., Lozhkin, A. V., Matveyeva, N. V., Murray, D. F., McGuire, A. D., Razzhivin, V. Y., Ritchie, J. C., Smith, B., Walker, D. A., Gajewski, K., Wolf, V., Holmqvist, B. H., Igarashi, Y., Kremenetskii, K., Paus, A., Pisaric, M. F. J., and Volkova, V. S.: Climate change and Arctic ecosystems: 1 . Vegetation changes north of $55^{\circ} \mathrm{N}$ between the 
last glacial maximum, mid-Holocene, and present, J. Geophys. Res., 108, 8170, doi:doi:10.1029/2002JD002558, 2003.

Braconnot, P., Otto-Bliesner, B., Harrison, S., Joussaume, S., Peterchmitt, J.-Y., Abe-Ouchi, A., Crucifix, M., Fichefet, T., Hewitt, C. D., Kageyama, M., Kitoh, A., Loutre, M.-F., Marti, O., Merkel, U., Ramstein, G., Valdes, P., Weber, S., Yu, Y., and Zhao, Y.: Coupled simulations of the mid-Holocene and Last Glacial Maximum: new results from PMIP2, Clim. Past Discuss., 2, 1293-1346, 2007,

http://www.clim-past-discuss.net/2/1293/2007/.

Brovkin, V., Ganopolski, A., and Svirezhev, Y.: A continuous climate-vegetation classification for use in climate-biosphere studies, Ecological Modelling, 101, 251-261, 1997.

Charbit, S., Ritz, C., Philippon, G., Peyaud, V., and Kageyama, M.: Numerical reconstructions of the Northern Hemisphere ice sheets through the last glacial-interglacial cycle, Clim. Past Discuss., 2, 879-921, 2006, http://www.clim-past-discuss.net/2/879/2006/.

Chen, M.-T., Huang, C.-C., Pflaumann, U., and M. Kucera, C. W.: Estimating glacial western Pacific sea-surface temperature: methodological overview and data compilation of surface sediment planktic foraminifer faunas, Quat. Sci. Rev., 24, 1049_ 1062, doi:10.1016/j.quascirev.2004.07.013, 2005.

Claquin, T., Roelandt, C., Kohfeld, K., Harrison, S., Tegen, I., Prentice, I., Balkanski, Y., Bergametti, G., Hansson, M., Mahowald, N., Rodhe, H., and Schulz, M.: Radiative forcing of climate by ice-age atmospheric dust, Clim. Dyn., 20, 193-202, doi:doi:10.1007/s00382-002-0269-1, 2003.

CLIMAP: Seasonal reconstructions of the Earth's surface at the last glacial maximum, Map and Chart Ser. \#36 ed., Geological Society of America, 1981.

Colinvaux, P. and de Oliveira, P.: Amazonian and neotropical plant communities on glacial time-scales: The failure of the aridity and refuge hypotheses, J. Quat. Sci., 15, 347-356, 2000.

Crosta, X. and Pichon, J.-J.: Application of modern analog technique to marine Antarctic diatoms : Reconstruction of maximum sea-ice extent at the Last Glacial Maximum, Paleoceanography, 13, 284-297, 1998a.

Crosta, X. and Pichon, J.-J.: Reapraisal of Antartica seasonal seaice at the Last Glacial Maximum, Geophys. Res. Lett., 25, $2703-$ 2706, 1998b.

Crucifix, M., Braconnot, P., Harrison, S., and Otto-Bliesner, B.: Second phase of Paleoclimate Modelling Intercomparison Project, EOS Trans AGU, 86, 264-265, 2005.

Cuffey, K. and Clow, G.: Temperature, accumulation, and ice sheet elevation in central Greenland through the last deglacial transition, J. Geophys. Res., 102, 26383-26396, 1997.

Curry, W. B. and Oppo, D. W.: Glacial water mass geometry and the distribution of $\delta^{13} \mathrm{C}$ of $\Sigma \mathrm{CO}_{2}$ in the western Atlantic Ocean, Paleoceanography, 20, 1017, doi:10.1029/2004PA001021, 2005.

Dällenbach, A., Blunier, T., Fluckiger, J., Stauffer, B., Chappellaz, J., and Raynaud, D.: Changes in the atmospheric $\mathrm{CH} 4$ gradient between Greenland and Antarctica during the Last Glacial and the transition to the Holocene, Geophys. Res. Lett., 27, 10051008, doi:10.1029/1999GL010873, 2000.

Dokken, T. and Jansen, E.: Rapid changes in the mechanism of ocean convection during the last glacial period, Nature, 401, 458-461, 1999

Driesschaert, E.: Climate change over the next millennia us- ing LOVECLIM, a new Earth system model including the polar ice sheets, Ph.D. thesis, Université Catholique de Louvain, Louvain-la-Neuve, Belgium, http://edoc.bib.ucl.ac.be: 81/ETD-db/collection/available/BelnUcetd-10172005-185914/, 2005.

Duplessy, J., Shackleton, N., Fairbanks, R., Labeyrie, L., Oppo, D., and Kallel, N.: Deep water source variations during the last climatic cycle and their impact on the global deepwater circulation, Paleoceanography, 3, 343-360, 1988.

Dupont, L., Jahns, S., Marret, F., and Ning, S.: Vegetation change in equatorial West Africa: time-slices for the last 150ka, Paleogeography, Paleoclimatology, Paleoecology, 155, 95-122, 2000.

Fluckiger, J., Dällenbach, A., Blunier, T., Stauffer, B., Stocker, T., Raynaud, D., and Barnola, J.-M.: Variations in Atmospheric N2O Concentration During Abrupt Climatic Changes, Science, 285, 227-230, doi:10.1126/science.285.5425.227, 1999.

Forsström, P.-L. and Greve, R.: Simulation of the Eurasian ice sheet dynamics during the last glaciation, Global Planet. Change, 42, 59-81, doi:10.1016/j.gloplacha.2003.11.003, 2004.

Ganopolski, A., Rahmstorf, S., Petoukhov, V., and Claussen, M.: Simulation of modern and glacial climates with a coupled model of intermediate complexity, Nature, 391, 351-356, 1998.

Gent, P. and Mcwilliams, J.: Isopycnal Mixing in Ocean Circulation Models, J. Phys. Oceanogr., 20, 150-155, doi:10.1175/ 1520-0485, 1990.

Gersonde, R. and Zielinski, U.: The reconstruction of late Quaternary Antarctic sea-ice distribution - the use of diatoms as a proxy for sea-ice, Paleogeography, Paleoclimatology, Paleoecology, 162, 263-286, 2000.

Gersonde, R., Abelmann, A., Brathauer, U., Becquey, S., Bianchi, C., Cortese, G., Grobe, H., Kuhn, G., Niebler, H.-S., Segl, M., Sieger, R., Zielinski, U., and Fütterer, D. K.: Last glacial sea surface temperatures and sea-ice extent in the Southern Ocean (Atlantic-Indian sector): A multiproxy approach, Palecoceanography, 18, 1061, doi:10.1029/2002PA000809, 2003.

Gersonde, R., Crosta, X., Abelmann, A., and Armand, L.: Seasurface temperature and sea ice distribution of the Southern Ocean at the EPILOG Last Glacial Maximum: a circumAntarctic view based on siliceous microfossil records, Quat. Sci. Rev., 24, 869-896, doi:10.1016/j.quascirev.2004.07.015, 2005.

Gherardi, J.-M., Labeyrie, L., McManus, J., Francois, R., Skinner, L., and Cortijo, E.: Evidence from the Northeastern Atlantic basin for variability in the rate of the meridional overturning circulation through the last deglaciation, Earth Planet. Sci. Lett., 240, 710-723, doi:10.1016/j.epsl.2005.09.061, 2005.

Goosse, H. and Fichefet, T.: Importance of ice-ocean interactions for the global ocean circulation: A model study, J. Geophys. Res., 104, 23 337-23 355, doi:10.1029/1999JC900215, 1999.

Goosse, H., Renssen, H., Timmermann, A., and Bradley, R. S.: Internal and forced climate variability during the last millennium: a model-data comparison using ensemble simulations, Quat. Sci. Rev., 24, 1345-1360, doi:10.1016/j.quascirev.2004.12.009, 2005.

Grousset, F., Biscaye, P., Revel, M., Petit, J., Pye, K., Joussaume, S., and Jouzel, J.: Antarctic (Dome C) ice-core dust at 18 k.y. B.P.: Isotopic constraints on origins, Earth Planet. Sci. Lett., 111, 175-182, 1992.

Harrison, S. and Prentice, C.: Climate and $\mathrm{CO}_{2}$ controls on global vegetation distribution at the last glacial maximum: analysis 
based on palaeovegetation data, biome modelling and palaeoclimate simulations, Global Change Biol., 9, 983-1004, 2003.

Hayes, A., Kucera, M., Kallel, N., Sbaffid, L., and Rohling, E.: Glacial Mediterranean sea surface temperatures based on planktonic foraminiferal assemblages, Quat. Sci. Rev., 24, 999-1016, doi:10.1016/j.quascirev.2004.02.018, 2005.

Hewitt, C., Stouffer, R., Broccoli, A., Mitchell, J., and Valdes, P. J.: The effect of ocean dynamics in a coupled GCM simulation of the Last Glacial Maximum, Clim. Dyn., 30, 203-218, doi:10. 1007/s00382-002-0272-6, 2003.

Hewitt, C., Broccoli, A., Crucifix, M., Gregory, J., Mitchell, J., and Stouffer, R.: The Effect of a Large Freshwater Perturbation on the Glacial North Atlantic Ocean Using a Coupled General Circulation Model, J. Climate, 19, 4436-4447, 2006.

Jost, A., Lunt, D., Kageyama, M., Abe-Ouchi, A., Peyron, O., Valdes, P. J., and Ramstein, G.: High-resolution simulations of the last glacial maximum climate over Europe: a solution to discrepancies with continental palaeoclimatic reconstructions?, Clim. Dyn., 24, 577-590, doi:10.1007/s00382-005-0009-4, 2005.

Joussaume, S. and Taylor, K.: Paleoclimate Modelling Intercomparison Project (PMIP), WCRP-111, WMO/TD-No. 1007, 9-24, 2000.

Kageyama, M. and Valdes, P. J.: Impact of the North American ice-sheet orography on the Last Glacial Maximum eddies and snowfall, Geophys. Res. Lett., 27, 1515-1518, doi:10.1029/ 1999GL011274, 2000.

Kageyama, M., Peyron, O., Pinot, S., Tarasov, P., Guiot, J., Joussaume, S., and Ramstein, G.: The Last Glacial Maximum climate over Europe and western Siberia : a PMIP comparison between models and data, Clim. Dyn., 17, 23-43, 2001.

Kageyama, M., Lainé, A., Abe-Ouchi, A., Braconnot, P., Cortijo, E., Crucifix, M., de Vernal, A., Guiot, J., Hewitt, C., Kitoh, A., Kucera, M., Marti, O., Ohgaito, R., Otto-Bliesner, B., Peltier, W., Rosell-Melé, A., Vettoretti, G., Weber, S., Yu, Y., and MARGO Projects Member: Last Glacial Maximum temperatures over the North Atlantic, Europe and western Siberia: a comparison between PMIP models, MARGO sea-surface temperatures and pollen-based reconstructions, Quat. Sci. Rev., 25, 2082-2102, doi:10.1016/j.quascirev.2006.02.010, 2006.

Kaplan, J., Bigelow, N., Prentice, I., Harrison, S., Bartlein, P., Christensen, T., Cramer, W., Matveyeva, N., McGuire, A., Murray, D., Razzhivin, V., Smith, B., Walker, D., Anderson, P., Andreev, A., Brubaker, L., Edwards, M., and Lozhkin, A.: Climate change and Arctic ecosystems: 2. Modeling, paleodatamodel comparisons, and future projections, J. Geophys. Res., 108, 8171, doi:10.1029/2002JD002559, 2003.

Kim, S.-J.: A Coupled Model Simulation of Ocean Thermohaline Properties of the Last Glacial Maximum, Atmosphere-Ocean, 42, 213-220, 2004.

Kitoh, A., Muramaki, S., and Koide, H.: A simulation of the Last Glacial Maximum with a coupled atmosphere-ocean, Geophys. Res. Lett., 28, 2221-2224, 2001.

Kucera, M., Rosell-Melé, A., Schneider, R., Waelbroeck, C., and Weinelte, M.: Multiproxy approach for the reconstruction of the glacial ocean surface (MARGO), Quat. Sci. Rev., 24, 813-819, doi:10.1016/j.quascirev.2004.07.017, 2005a.

Kucera, M., Weinelt, M., Kiefer, T., Pflaumann, U., Hayes, A., Weinelt, M., Chen, M.-T., Mix, A., Barrows, T., Cortijo, E.,
Duprat, J., Juggins, S., and Waelbroeck, C.: Reconstruction of sea-surface temperatures from assemblages of planktonic foraminifera: multi-technique approach based on geographically constrained calibration data sets and its application to glacial Atlantic and Pacific Oceans, Quat. Sci. Rev., 24, 951-998, doi: 10.1016/j.quascirev.2004.07.014, 2005b.

Labeyrie, L., Duplessy, J.-C., Duprat, J., Juillet-Leclerc, A., Moyes, J., Michel, E., Kallel, N., and Shackleton, N.: Changes in the vertical structure of the North Atlantic ocean between Glacial and Modern times, Quat. Sci. Rev., 11, 401-413, 1992.

Lambeck, K. and Chappell, J.: Sea Level Change Through the Last Glacial Cycle, Science, 292, 679-686, 2001.

Leal, M.: The African rain forest during the last glacial maximum, an archipelago of forests in a sea of grass, Ph.D. thesis, ISBN: 90-8504-037-X., Wageningen, University, 2004.

Marchal, O., Francois, R., Stocker, T., and Joos, F.: Ocean thermohaline circulation and sedimentary ${ }^{231} \mathrm{~Pa} /{ }^{230} \mathrm{Th}$ ratio, Paleoceanography, 15, 625-641, 2000.

McManus, J., Francois, R., Gherardi, J., Keigwin, L., and BrownLeger, S.: Collapse and rapid resumption of Atlantic meridional circulation linked to deglacial climate changes, Nature, 428, 834-837, 2004.

Meland, M. Y., Jansen, E., and Elderfield, H.: Constraints on SST estimates for the northern North Atlantic/Nordic Seas during the LGM, Quat. Sci. Rev., 24, 835-852, doi:10.1016/j.quascirev. 2004.05.011, 2005.

Mix, A.: Chilled out in the ice-age Atlantic, Nature, 425, 32-33, 2003.

Monnin, E., Indermuele, A., Daellenbach, A., Flueckiger, J., Stauffer, B., Stocker, T., Raynaud, D., and Barnola, J.-M.: Atmospheric $\mathrm{CO}_{2}$ Concentrations over the Last Glacial Termination, Science, 291, 112-114, 2001.

Oppo, D. W. and Lehman, S. J.: Mid-Depth Circulation of the Subpolar North Atlantic During the Last Glacial Maximum , Science, 259, 1148-1152, doi:10.1126/science.259.5098.1148, 1993.

Opsteegh, J., Haarsma, R., Selten, F., and Kattenberg, A.: ECBILT: A dynamic alternative to mixed boundary conditions in ocean models, Tellus, 50, 348-367, http://www.knmi.nl/ selten/ tellus97.ps.Z, 1998.

Paul, A. and Schäfer-Neth, C.: Modeling the water masses of the Atlantic Ocean at the Last Glacial Maximum, Paleoceanography, 18, 1058, doi:10.1029/2002PA000783, 2003.

Paul, A. and Schäfer-Neth, C.: How to combine sparse proxy data and coupled climate models, Quat. Sci. Rev., 24, 1095-1107, doi: 10.1016/j.quascirev.2004.05.010, 2005.

Peltier, W.: Global Glacial Isostasy and the Surface of the Ice-Age Earth: The ICE-5G (VM2) Model and GRACE, Ann. Rev. Earth Planet. Sci., 32, 111-149, doi:10.1146/annurev.earth.32.082503. 144359, 2004.

Peyron, O., Bégeot, C., Brewer, S., Heiri, O., Magny, M., Millet, L., Ruffaldi, P., Campo, E. V., and Yu, G.: Lateglacial climate in the Jura mountains (france) based on different quantitative reconstruction approaches from pollen, lake-levels, and chironomids, Quat. Res., 64, 197-211, doi:10.1016/j.yqres.2005.01.006, 2005.

Pflaumann, U., Sarnthein, M., Chapman, M., d'Abreu, L., Funnell, B., Huels, M., Kiefer, T., Maslin, M., Schulz, H., Swallow, J., van Kreveld, S., Vautravers, M., Vogelsang, E., and Weinelt, M.: Glacial North Atlantic: Sea-surface conditions re- 
constructed by GLAMAP 2000, Paleoceanography, 18, 1065, doi:10.1029/2002PA000774, 2003.

Prentice, I., Cramer, W., Harrison, S., Leemans, R., Monserud, R., and Solomon, A.: A golbal biome model based on plant physiology and dominance, soil properties and climate, J. Biogeography, 19, 117-134, 1992.

Prentice, I., Jolly, D., and BIOME 6000 participants: Mid-Holocene and glacial-maximum vegetation geography of the northern continents and Africa, J. Biogeography, 27, 507-519, 2000.

Rahmstorf, S.: Ocean circulation and climate during the past 120,000 years, Nature, 419, 207-214, 2002.

Ray, N. and Adams, J.: A GIS-based Vegetation Map of the World at the Last Glacial Maximum (25,000-15,000 BP), Internet Archaeol, 11, http://intarch.ac.uk/journal/issue11/rayadams_toc. html, 2001.

Renssen, H. and Vandenberghe, J.: Investigation of the relationship between permafrost distribution in NW Europe and extensive sea-ice cover in the North Atlantic Ocean during the cold phases of the Last Glaciation, Quat. Sci. Rev., 22, 209-223, 2003.

Renssen, H., Goosse, H., and Fichefet, T.: Contrasting trends in North Atlantic deep-water formation in the Labrador Sea and Nordic Seas during the Holocene, Geophys. Res. Lett., 32, L08 711, doi:10.1029/2005GL022462, http://www.agu.org/ journals/gl/g10508/2005GL022462/2005GL022462.pdf, 2005.

Sarnthein, M., Gersonde, R., Niebler, S., Pflaumann, U., Spielhagen, R., Thiede, J., Wefer, G., and Weinelt, M.: Overview of Glacial Atlantic Ocean Mapping (GLAMAP 2000), Paleoceanograhy, 18, 1030, doi:10.1029/2002PA000769, 2003.

Shin, S.-L., Liu, Z., Otto-Bliesner, B., Brady, E., Kutzbach, J., and Harrison, S.: A simulation of the Last Glacial Maximum climate using the NCAR-CCSM, Clim. Dyn., 20, 127-151, 2003.
Svendsen, J., Alexanderson, H., Astakhov, V., Demidov, I., Dowdeswell, J., Funder, S., Gataullin, V., Henriksen, M., Hjort, C., Houmark-Nielsen, M., Ingólfsson, H. H. O., Jakobsson, M., Kjaer, K., Larsen, E., Lokrantz, H., Lunkka, J., Lysa, A., Mangerud, J., Matiouchkov, A., Murray, A., Möller, P., Niessen, F., Nikolskaya, O., Polyak, L., Saarnisto, M., Siegert, C., Siegert, M., Spielhagen, R., and Stein, R.: Late Quaternary ice sheet history of northern Eurasia, Quat. Sci. Rev., 23, 1229-1271, doi: 10.1016/j.quascirev.2003.12.008, 2004.

Tarasov, P., Peyron, O., Guiot, J., Brewer, S., Volkova, V., Bezusko, L., Dorofeyuk, N., Kvavadze, E., Osipova, I., and Panova, N.: Last glacial maximum climate of the former Soviet Union and Mongolia reconstructed from pollen and macrofossil data., Clim. Dyn., 15, 227-240, 1999.

Timmermann, A. and Goosse, H.: Is the wind stress forcing essential for the meridional overturning circulation?, Geophys. Res. Lett., 31, L04 303, doi:10.1029/2003GL018777, 2004.

Vettoretti, G., Peltier, W., and McFarlane, N.: Global water balance and atmospheric water vapour transport at last glacial maximum: climate simulations with the Canadian Climate Centre for Modelling and Analysis atmospheric general circulation model, Can. J. Earth Sci., 37, 695-723, doi:10.1016/j.quascirev.2006.02.010, 2000.

Weber, S., Drijfhout, S., Abe-Ouchi, A., Crucifix, M., Eby, M., Ganopolski, A., Murakami, S., Otto-Bliesner, B., and Peltier, W.: The modern and glacial overturning circulation in the Atlantic ocean in PMIP coupled model simulations, Clim. Past, 2, 923-949, doi:1814-9359/cpd/2006-2-923, 2007.

Williams, J.: Variations in tree cover in North America since the last glacial maximum, Global Planet. Change, 35, 1-23, 2002.

Yu, E.-F., Francois, R., and Bacon, M. P.: Similar rates of modern and last-glacial ocean thermohaline circulation inferred from radiochemical data, Nature, 379, 689-694, doi:10.1038/379689a0, 1996. 